\title{
VÝSLEDKY ARCHEOLOGICKÝCH VÝZKUMŮ V ZAHRADÁCH NĚKDEJŠÍHO KLÁŠTERA HORTUS REGIS NA STARÉM BRNĚ
}

\author{
ANTONÍN ZŮBEK
}

Abstrakt: Př́spèvek shrnuje výsledky záchranných archeologických výzkumů, které se v letech 2008 až 2013 realizovaly ve východni ćásti areálu Fakultní nemocnice u sv. Anny v Brně (Pekařská 53). Jedná se o inundační území, které bylo využiváno jako klášterní zahrada a následně jako nemocniční park. Popsány jsou zkoumané archeologické situace z obdobi 14. až 20. století.

Klíčová slova: středověk-novověk-Brno-klášter.

Results of Archaeological Research into the Gardens of the Former Hortus Regis Monastery in Old Brno

Abstract: This article sums up the results of archaeological research carried out in 2008-2013 in the east section of the complex of St. Anne's University Hospital, Brno (Pekařská Street 53). This inundation area was once used as a monastery garden and later as a hospital park. The paper describes archaeological contexts from the period spanning the 14th century and the 20th century.

Key words: Middle Ages - modern age - Brno - monastery.

\section{1 Úvod}

Cílem př́spěvku je shrnout poznatky záchranných archeologických výzkumů, které se v letech 2008 až 2013 realizovaly ve východní části areálu Fakultní nemocnice u sv. Anny v Brně (Pekařská 53). Jejich provedení zajistila společnost Archaia Brno, o. p. s. Postihly poměrně rozsáhlý prostor, který byl původně součástí pozemků kláštera dominikánek s oratoriem sv. Anny, zvaný Hortus regis (obr. 1). Výzkumy byly vyvolány stavbou „Fakultní nemocnice u sv. Anny v Brně - stavba ICRC“, parc. č. 1752/1, 1752/2. Jejím účelem bylo vybudování nového pavilonu Mezinárodního centra klinického výzkumu. Jeho výstavba probíhala ve dvou základních etapách. $Z$ tohoto důvodu byl rovněž archeologický výzkum rozdělen do dvou fází. Terénní část první etapy se uskutečnila v období od října 2008 do února 2009 a obsáhla východní část stavební jámy (akce č. A66/2008 - Černá-Sedláčková-Zůbek 2010; Holub a kol. 2009, 367-368; Holub a kol. 2010, 424-426), druhá etapa proběhla od dubna 2012 do května 2013 a zahrnovala západní část (akce č. A36/2012 - Černá a kol. 2013, 168-170; Černá a kol. 2014, 190-193; Černá-Zůbek 2013). V listopadu 2010 až březnu 2011 byl ještě realizován archeologický dohled nad dotěžováním východní partie stavební jámy mechanizací (akce č. A87/2010 - Zůbek 2017). Uvedeným archeologickým výzkumům předcházela dokumentace deseti zjištovacích sond, které byly v období od listopadu 2006 do dubna 2007 rozmístěny v ploše budoucí stavby (akce č. A106/2006 Holub a kol. 2007, 444-445; Peška 2007). Od ledna do dubna 2007 byla ještě zkoumána menší plocha při Anenské ulici vedle severovýchodního nároží hlavní budovy nemocnice (obr. 4). Její výzkum souvisel s prípravnými pracemi před výstavbou kliniky ICRC, konkrétně s vybudováním energobloku (akce č. A1/2007 - Holub a kol. 2008, 381-383; Zapletalová 2007).

\section{Stručná historie kláštera}

Vznik konventu dominikánek s oratoriem sv. Anny, zvaný Hortus regis, náležel k druhé vlně zakládání brněnských řeholních institucí, která přišla s obdobím 14. století. $\mathrm{V}$ předešlém věku došlo ke „spontánnímu“ vybudování klášterů dominikánů a minoritů v prostoru vlastního města (Černušák 2013, 718-719; Foltýn a kol. 2005, 154-160, 167-172; Peška 2015). Budovy nových klášterů byly situovány mimo okruh městských hradeb a jejich fundátory byli členové panovnického rodu. Klášter dominikánek založený v roce 1312 byl nejstarší z těchto fundací. V roce 1323 následovalo založení kláštera cisterciaček Aula Sanctae Mariae na Starém Brně (Foltýn a kol. 2005, 208-215). V polovině 14. století vznikl konvent augustiniánů s kostelem 


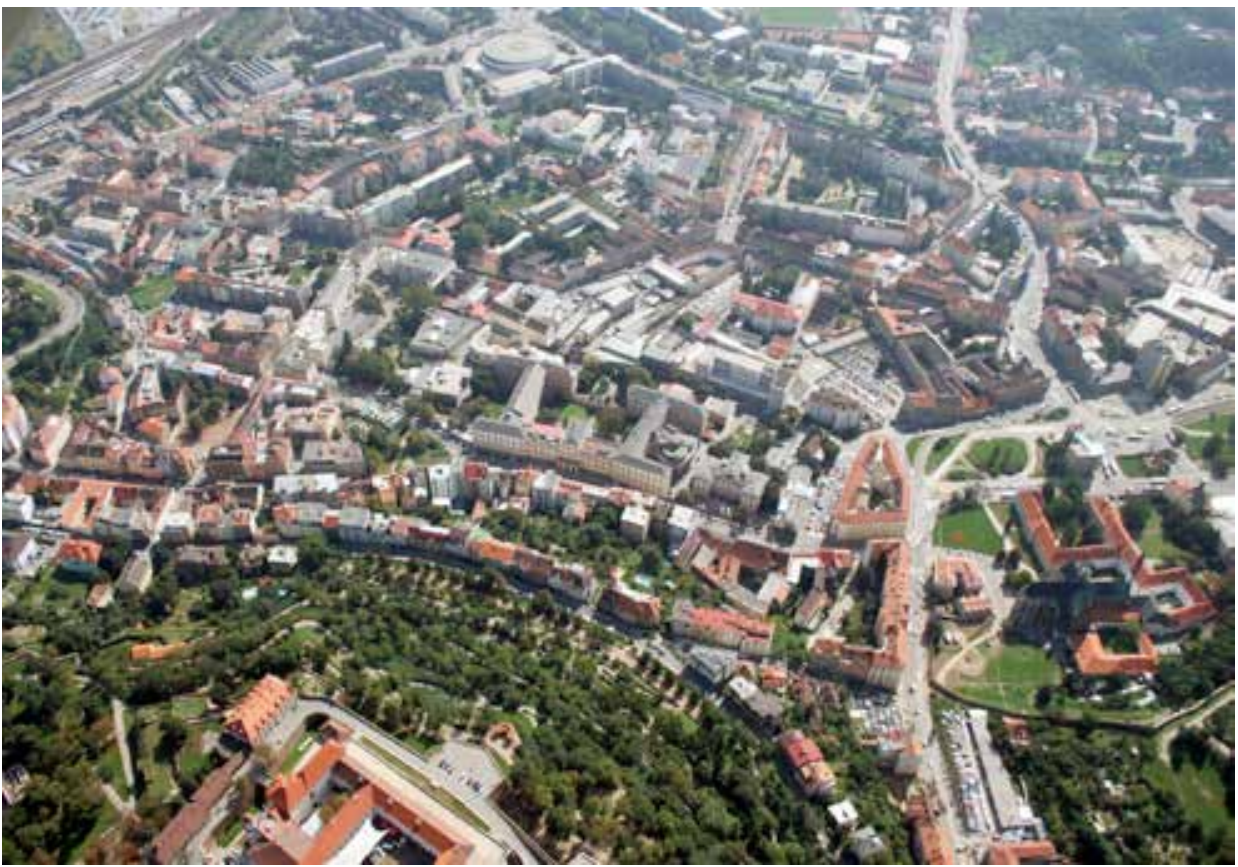

Obr. 1. Letecký pohled od severu na areál Fakultní nemocnice u sv. Anny a nejbližší okolí z roku 2006 před výstavbou nových pavilonů. Zdroj Fotoarchiv Archaia Brno, o. p. s. - foto č. 9331-2006.

Abb. 1. Luftansicht von Norden auf das Areal des Fakultätskrankenhauses bei St. Anna und seine nächste Umgebung aus dem Jahr 2006 vor dem Bau neuer Pavillons. Quelle Archaia Brno, o. p. s. - Foto Nr. 9331-2006.

Zvěstování Panně Marii a sv. Tomáše v severním předpolí města (dnes Moravské náměstí - Foltýn a kol. 2005, 173-180). Posledním počinem bylo vysazení kartouzy Cella Trinitatis v Králově Poli na přelomu 60. a 70. let 14. století (Žák 1929; Bukovský 1994; Jan 2004; Kocman 2004; Řepa 2004, 99-102; Foltýn a kol. 2005, 196-200). Klášter Hortus regis byl v pořadí druhým brněnským konventem dominikánek. První měl své sídlo uvnitř hradeb při kostele Nanebevzetí Panny Marie a byl ustanoven již v první polovině 13. století. Nazýval se Cella Sanctae Mariae nebo herburský klášter (Foltýn a kol. 2005, 160-167). Bezprostředním sousedem dominikánek u sv. Anny byla na západní straně komenda johanitů, jejíž počátky spadají do roku 1243, kdy do jejich řádu vstoupil i se svými majetky včetně zdejšího špitálu sv. Ducha brněnský měšt’an Rutger (ke starobrněnským johanitům Foltýn a kol. 2005, 202-205, tam i další prameny a literatura; nově např. Mitáček 2005).

Fundaci kláštera dominikánek u sv. Anny provedl Jan Lucemburský. Ze zakládací listiny se dovídáme, že tak učinil na přání své manželky Elišky, a naplnil někdejší záměr svého tchána krále Václava II. (CDM VI, 42-43 č. 58). Klášter byl založen v místě, jemuž se říkalo Zahrada královská (Hortus regis). Šlo o královský majetek, který panovník k výstavbě kláštera poskytl. Tvořil ho ovocný sad, dvůr s věží a zahrada. Ta se rozprostírala až ke špitálu, který náležel ke komendě johanitů. Správu kláštera svěřil král Jan paní Kateřině, vdově po Tasovi z Lomnice, která se zřejmě stala také první abatyší. Ta výrazným způsobem vstoupila do procesu vzniku kláštera, když ho v roce 1317 vybavila základním majetkem (CDM VI, 80-82 č. 109). Nadání rozšíríila ve svém testamentu z roku 1333 (CDM VI, 354 č. 463). Rod pánů z Lomnice postupně daroval klášteru další majetky a udržel si vliv na jeho chod jako vlastní držitel zakladatelských práv. Členky rodu bývaly často jeho představenými. Královský rod kromě vlastního fundačního 
aktu a darování pozemku pro stavbu kláštera a určitého dalšího majetku bezprostřední vliv na klášter neměl. Členkami konventu se stávaly ženy ze šlechtického i městského prostředí (hlavně z předních brněnských měštanských rodů). Nevelký majetek se díky odkazům jeho ochránců a obyvatel Brna postupně zvětšoval, povětšinou šlo ale o menší nemovitosti. V 15 . století upadal a ztratil mnoho svých statků. Kolem poloviny 16. století připadl klášter panovnické komoře. Ale ani to nezastavilo jeho chudnutí. Těžce byl klášter poškozen během obléhání města Švédy $\mathrm{v}$ roce 1643 a především 1645 . Obnoven byl v roce 1650 , kdy se do něho navrátily sestry, které se uchýlily pod ochranu městských hradeb (počátkem 18. století je doložen jejich dům na Kozí ulici). V roce 1738 byl klášter barokně upraven, v roce 1768 byl renovován kostel. V té době žilo v klášteře společenství čítající asi čtyřicet řeholnic.

V roce 1782 byl konvent dekretem císaře Josefa II. zrušen a jeho areál byl „Zveřejněn“. V roce 1783 sem byl přmemístěn na krátkou dobu vojenský špitál. Poměrně komplikovaným způsobem a řadou dislokačních přesunů zde nakonec v roce 1786 vznikl Císařsko-královský všeobecný zaopatřovací ústav, který pod jedno vedení soustředil nemocnici, porodnici, nalezinec a ústav pomatených. Roku 1856 se změnil na Zemskou veřejnou všeobecnou nemocnici v Brně. Když přestaly klášterní budovy jejímu provozu dostačovat, bylo rozhodnuto o jejich přestavbě. Zahájena byla v roce 1865. Během ní se však zjistilo, že hrozí zrrícení budov. Proto byla postavena zcela nová stavba, dokončena byla v roce 1868. Areál nemocnice byl ještě do začátku 20. století rozšířen. Když v roce 1893 vyhořela textilní továrna v jižním sousedství při dnešní Hybešově ulici a zemský výbor nepovolil její obnovu, byla společně se sousedními domy zakoupena pro nemocniční účely. V roce 1900 byla v západním sousedství odkoupena johanitská komenda, v roce 1910 byla pak zbourána.

Dějiny kláštera nebyly dosud monograficky v úplnosti zpracovány, ostatně stejně jako historie většiny středověkých a novověkých brněnských konventů. K dispozici je pouze několik dílčích statí a stručných souhrnů, z nichž vycházel text předcházejících odstavců (z novějších např. Černušák 2013, 725; Foltýn a kol. 2005, 205-208; Kuča 2000, 571-572; Flodrová-Müller 2007, 73-74). K poznání historického vývoje brněnské fakultní nemocnice lze využít publikace autorů J. Sajnera, L. Selinger a K. Volavého (1986) a D. Černouškové a D. Hodečka (1996). Vypracován byl stavebně-historický průzkum (Borský-Černoušková-Hodeček 1994).

\section{Topografická pozice}

Zkoumaný prostor byl součástí inundačního území na levém břehu vodoteče, která byla označována jako Svratecký náhon (obr. 1-3). Pravděpodobně se jednalo o upravený tok vedlejšího ramene řeky Svratky. Ten po celá staletí tvořil výrazný prvek zdejší krajiny. Dnes je zkanalizován a zasypán. Segment jeho linie se odráží například ve vytyčení Vodní ulice. Protékal západní a jižní částí dnešního areálu fakultní nemocnice. ${ }^{1}$ Svým průběhem uzavíral dané území do celku, který na severu ohraničoval svah Špilberku a na východě sráz skalního ostrohu Petrova. Lokálně výrazným prvkem byl při úpatí svahu Špilberku tzv. Provaznický vršek (Lochenberg dnes přibližně Kopečná 43). Vodní režim doplňoval ve východní části potůček ze studánky pod Petrovem (později zvané Fons salutis), který byl levostranným přítokem Svrateckého náhonu. $\mathrm{Z}$ jižního svahu špilberského kopce snad stékal také potok, který ústil do náhonu někde v místech kaple fakultní nemocnice (Flodrová-Müller 2007, 43). Nedostatkem vody tedy předmětné území netrpělo. Její přebytek posilovaný svodem deštové vody po svazích zmíněných vrcholů se mohl kumulovat ve zcela plochých nejnižších partiích inundace, zvláště když vsakování ztěžovala přirozeně vysoká hladina spodní vody v blízkosti vodoteče. To se mohlo týkat především východního cípu území. Šlo o silně zamokřený terén. Měla se zde údajně nacházet bažinatá městská louka, zvaná (od 15. století) Žabí louže (Lacus ranarum). Později byl prostor označován jako Lackerwiese (,loužová louka“ - Kuča 2000, 372, 373). Informace písemných pramenů podpořily poznatky archeologických výzkumů a výsledky př́rodovědných analýz ( $\mathrm{k}$ tomu např.

1 Segmenty náhonu v areálu nemocnice byly zkoumány při záchranných archeologických výzkumech v roce 1989 v jeho západní části (Procházka 1990) a v roce 1996 v jižní části (Procházka 1999). 


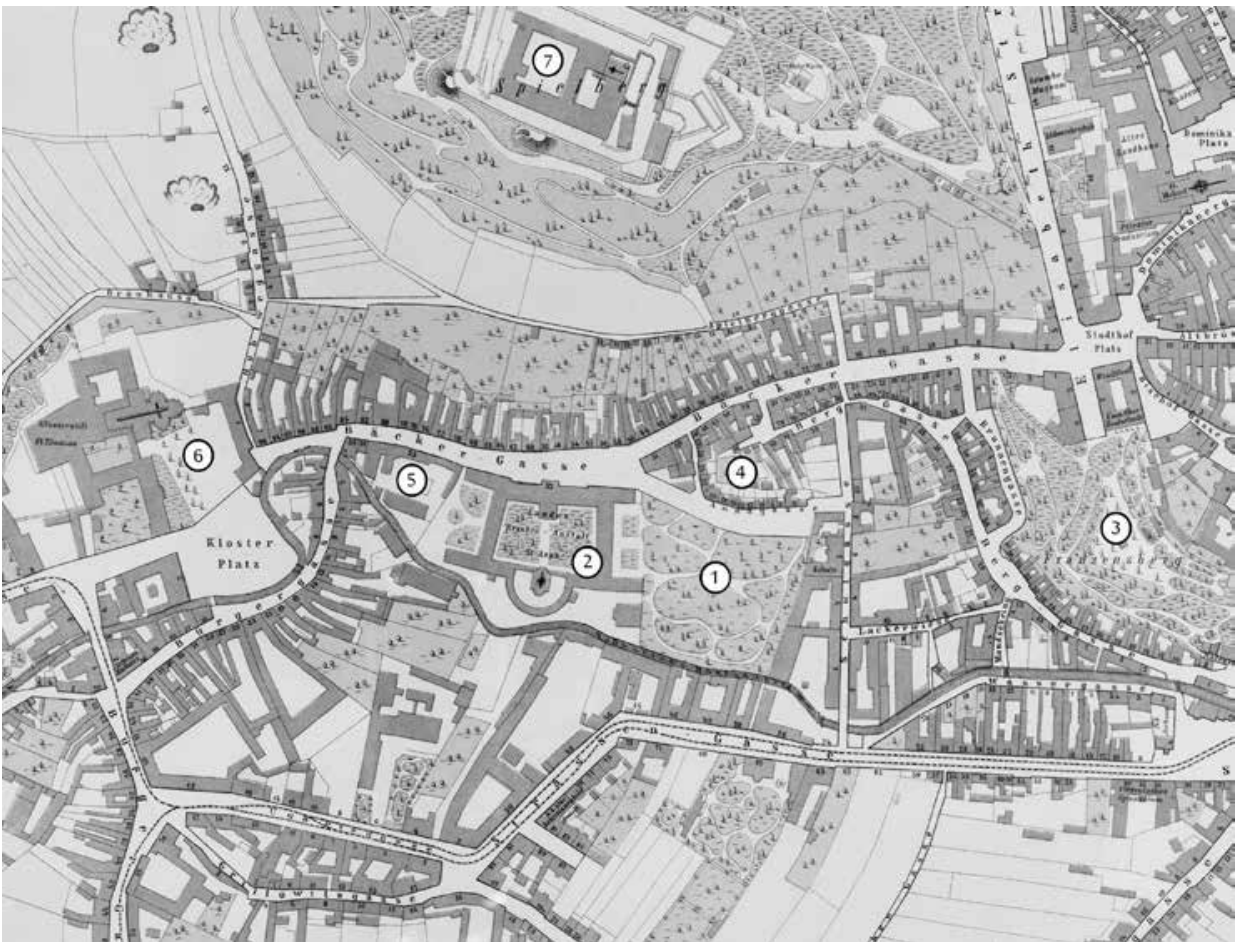

Obr. 2. Výřez z plánu z roku 1885 s územím kolem nemocnice u sv. Anny (Archiv města Brna, fond U 9, sign. K42). Čísla v bílých kroužcích označují polohu v textu zmiňovaných míst. 1 - areál nemocničního parku (někdejší klášterní zahrada); 2 - hlavní budova nemocnice; 3 - Petrov se skalním výběžkem zvaným Puhlík (později Františkov); 4 - Provaznický vršek; 5 - johanitská komenda; 6 - klášter cisterciaček na Starém Brně; 7 - Špilberk.

Abb. 2. Ausschnitt aus einem Plan von 1885 mit dem Gebiet um das Krankenhaus bei St. Anna (Archiv der Stadt Brno, Bestand U 9, Sign. K42). Die Ziffern in den weißen Kreisen kennzeichnen die Lage der im Text erwähnten Orte. 1 - Areal des Krankenhausparks (ehemaliger Klostergarten); 2 - Hauptgebäude des Krankenhauses; 3 - Petersberg mit Puhlik genanntem Felsenausläufer (später Franzensberg); 4 - Seilerberg, 5 - Johanniterkommende; 6 - Zisterzienser Nonnenkloster in Alt Brünn; 7 - Spielberg.

Zapletalová a kol. 2005). Bažinatá byla zřejmě i část protilehlého pravobřeží Svrateckého náhonu, která dokázala plnit dnes již zaniklý potok (později zvaný Novosadský), který tekl směrem na Nové sady a Trnitou.

Popsané území bylo rozloženo mezi novým Brnem na východní a Starým Brnem na západní straně. Město Brno se začalo rozvíjet od přelomu 12. a 13. století a stalo se postupně dominantním sídelním prvkem kraje. Staré Brno navazovalo na starší osídlení. Bývá sem situováno centrum s hradem brněnských knížat z 11.-12. století (nejnověji s přehledem literatury a pramenů Procházka-Wihoda-Zapletalová 2011, 515-540; Kolařík-Merta-Zůbek 2014). Ve středověku představovalo Staré Brno obtížně zařaditelný útvar s vlastním rychtářem a blížilo se postavení městečka (Flodrová-Müller 2007; Doležel 2000, 172-174; Kuča 2000, 518-535; Procházka-Kolařík-Zůbek 2013, 558-568). Spojnici sídel tvořila Pekařská ulice vedoucí po úbočí špilberského kopce (původně Velká Pekařská - Grosse Bäckergasse, ve středověku Peckyngasse či platea Pistorum - Flodrová 1997, 178). Podél její dolní (západní) části byl na východním obvodu Starého Brna vybudován areál komendy johanitského řádu s př́slušným zázemím. Byl bezprostředním sousedem kláštera dominikánek u sv. Anny. Ten byl postaven rovněž při Pekařské ulici 


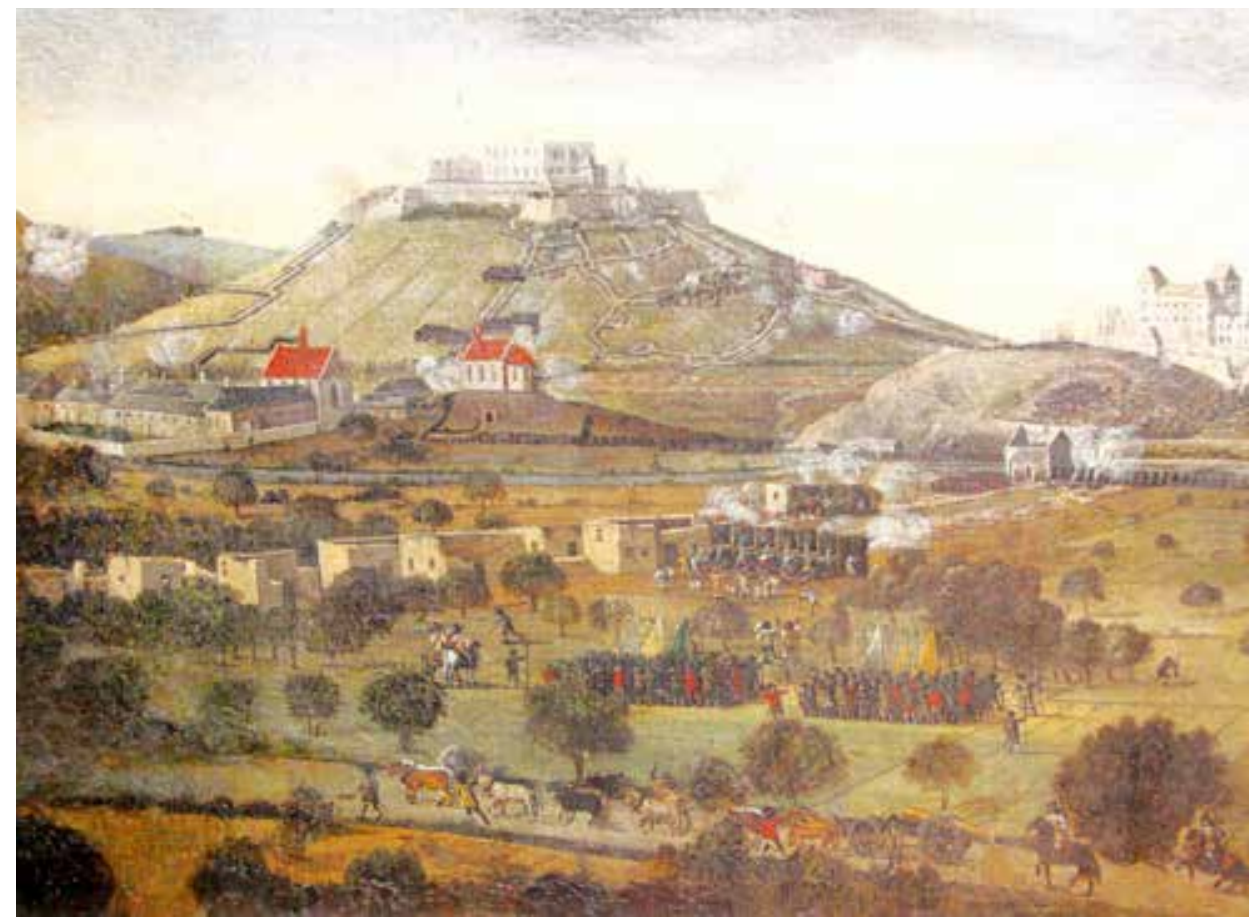

Obr. 3. Výřez z obrazu H. B. Bayera - H. J. Zeisera, Obležení Brna Švédy 3. května až 20. srpna 1645, pohled na Brno od jihu (uložen v MuMB, inv. č. 2285). V pozadí patrný hrad Špilberk, pod ním vlevo klášter dominikánek u sv. Anny, vpravo od něj na Provaznickém vršku kostel Všech svatých. Na originále či velmi kvalitní barevné reprodukci jsou pod Provaznickým vrškem patrné dvě vodní plochy (jednou z nich je snad dokumentovaná situace s. s. j. 051).

Abb. 3. Ausschnitt aus einem Bild von H. B. Bayer-H. J. Zeiser, Belagerung Brünns durch die Schweden vom 3. Mai bis zum 20. August 1645, Blick auf Brünn von Süden (aufgewahrt im Museum der Stadt Brno, Inv.-Nr. 2285). Im Hintergrund ist der Spielberg zu sehen, unterhalb von ihm links das Dominikanerinnenkloster zu St. Anna, links davon auf dem Seilerberg die Allerheiligenkirche. Auf dem Original oder auf einer qualitativ hochwertigen Farbreproduktion sind unterhalb des Seilerbergs zwei Wasserflächen zu sehen (eine von ihnen wahrscheinlich dokumentiert durch die Situation stratigraphischer Verband 051).

a jeho areál se rozprostíral na jihu až ke Svrateckému náhonu. Na východě jeho majetek sousedil se zmíněnou zamokřenou městskou loukou.

Nad východní partií klášterního pozemku se vypínal Provaznický vršek. Existovalo zde staré osídlení, které bylo ve středověku označováno jako statek kostela Všech svatých. Lidé sídlící kolem kostela nebyli z hlediska právního postavení typickými představiteli předměstí, ale ani klasickými poddanými cizí vrchnosti, město zde nepochybně uplatňovalo svoji soudní svrchovanost a alespoň v některých letech vybíralo městskou sbírku (Procházka-Kolařík-Zůbek 2013, 568). Byl vysloven názor, že šlo o samostatnou osadu s rychtářem a konšely, jejíž vrchností byl farář u Všech svatých (Dřímal 1973, 264, 265). Pod východním úpatím Provaznického vršku se od Pekařské ulice odkláněla komunikace, která směřovala podél úpatí Petrova, kolem Žabí louky ke Svrateckému náhonu. Později se z ní vyvinula Kopečná ulice (původně Malá Pekařská - Kleine Bäckergasse - Flodrová 1997, 119). Při její střrední partii existovalo osídlení zvané „chudí pod Puhlíkem“ (Procházka-Kolařík-Zůbek 2013, 597; Vičar 1966, 234). Termínem „Puhlík“ se ve středověku rozuměl výběžek Petrova v prostoru dnešních Denisových sadů (dříve také Františkov). V místech uvedených sídlišt' vzniklo osídlení nejpozději ve 12. století (Procházka-Wihoda-Zapletalová 2011, 538). 
Prostor, na němž byl klášter dominikánek vybudován, se zřejmě nacházel v těsné blízkosti někdejšího mocenského centra a byl obklopen sídelními útvary, které předcházely založení středověkého města. Vznikaly na místech s příhodnými podmínkami, jako byla např́íklad úpatí svahů nad inundačním územím. Vlastní budovy konventu s kostelem byly postaveny poněkud dále od náhonu již na mírně se zvedajícím úpatí špilberského kopce při Pekařské ulici. Dnes jde v podstatě o prostor hlavní nemocniční budovy. Výhodnosti této polohy vůči dosahu vody zřejmě využil již klášteru darovaný královský „dvůr s věží“, na jehož místě byl areál konventu pravděpodobně vystavěn. Otázkou zůstává stáří tohoto dvorce, případně možnost osídlení a význam místa v období 11.-12. století. Jedna z hypotéz právě sem umist'uje hrad brněnských knížat (Zřídkaveselý 1998, 7-8; 2013). Archeologické výzkumy se v prostoru hlavní nemocniční budovy zatím nerealizovaly. Nejblíže byla zkoumána plocha při jejím severovýchodním nároží. Jedinou situací, která by mohla s dvorcem souviset či náležet ještě staršímu osídlení, zde byla zahloubená pec, která byla přiřazena do období druhé poloviny 12. až první poloviny 13. století (Holub a kol. 2008, 383; Procházka-Wihoda-Zapletalová 2011, 538).

Po zrušení kláštera v 18. století se na jeho pozemcích etabloval katastrální celek zvaný Území Svaté Anny (po krátkou dobu v první polovině 20. století U Svaté Anny). Na západě sousedil se Starým Brnem, osídlení podél Pekařské ulice náleželo ke katastru Velká a Malá Pekařská ulice, na východě bylo po zavezení zamokřené louky vyčleněno samostatné katastrální území Lackerwiese (ve 20. a 30. letech 20. století V Jircháŕích). Při katastrální reformě ve 40. letech 20. století svatoanenský katastr zanikl a byl z velké části připojen ke Starému Brnu (Kuča 2000, $372,373,476-483,571-573)$.

O nejstarší podobě kláštera nevíme takřka nic. Rovněž na jeho mladší stavební vývoj lze díky rozsáhlým přestavbám $\mathrm{v} 19$. století nazírat pouze prostřednictvím archivních materiálů (především vedut, plánů a fotografií - k tomu viz Foltýn a kol. 2005, 206-207; Kroupa-Suchánek 2015, 681-682; Mezihoráková 2016, 40-43). Z nich je celkem jasně patrné, že východní část pozemku nebyla zastavěna a sloužila jako zahrada, popř́ípadě jako bezprostřední hospodářská půda konventu. ${ }^{2}$ Účel využití zřejmě silně ovlivňovala skutečnost, že jde o zcela plochý, před vodou nechráněný inundační terén. $V$ pozdějším období se zde nacházela nemocniční zahrada, postupně zastavovaná novými budovami nemocnice. A právě v tomto prostoru byly provedeny archeologické výzkumy, o jejichž výsledcích předložená stat' referuje.

\section{Archeologický výzkum}

Archeologické výzkumy v letech 2008 až 2013 probíhaly v koordinaci se stavebními pracemi. Aby došlo k co nejmenšímu omezení časového harmonogramu výstavby, byla většina ploch zkoumána $\mathrm{v}$ předstihu před zahájením stavební činnosti. Výzkumu byla podrobena vybraná volná prostranství mimo zástavbu, vyhýbající se komunikacím a objektům tak, aby zůstal zachován provoz nemocnice. Během první fáze byly ve východní části areálu při postupném rozšiřování zkoumány dvě základní plochy (sonda S1-S5 a sonda S2-S3-S4). Ve druhé fázi výzkumu byly v západní části vytyčeny tři sondy (S1, S2, S3). Plochy původně nepřístupné pro archeologický výzkum byly podrobeny pouze archeologickému dohledu během zemních prací stavby. Svým způsobem je nutné akci z let 2008 až 2013 označit za postupný „,sondážní výzkum“. Stavební jáma budovaného pavilonu zabrala plochu přibližně $8000 \mathrm{~m}^{2}$. Celková výměra zkoumaných sond činila $1500 \mathrm{~m}^{2}$ (obr. 4). Hloubka zemních prací dosahovala 5,5 m.

Zasažený terén byl tvořen souvrstvím, které lze rozdělit na dvě základní části. Spodní byla tvořena náplavovými vrstvami (ca $3 \mathrm{~m}$ - 197,0 až 200,0 m n. m.), svrchními uloženinami antropogenního původu (ca 2,5 m - 200,0 až 202,5 m n. m.), přičemž dominantní podíl představovaly navážkové vrstvy (obr. 5).

Archeologickým výzkumem byl získán nálezový soubor čítající na 45000 položek z období 14. až 20. století. Největší podíl tvoří zlomky keramických nádob. Dále jsou zastoupeny

2 Např́iklad obraz Folperta van Ouden van Allena, asi okolo roku 1690, uložený ve sbírkách Muzea města Brna, nebo plány z let 1699 , 1729 a 1741 uložené v Österreichisches Staatsarchiv - Kriegsarchiv, Inland C IV a) Brünn Nr. 11, 12, 13. 


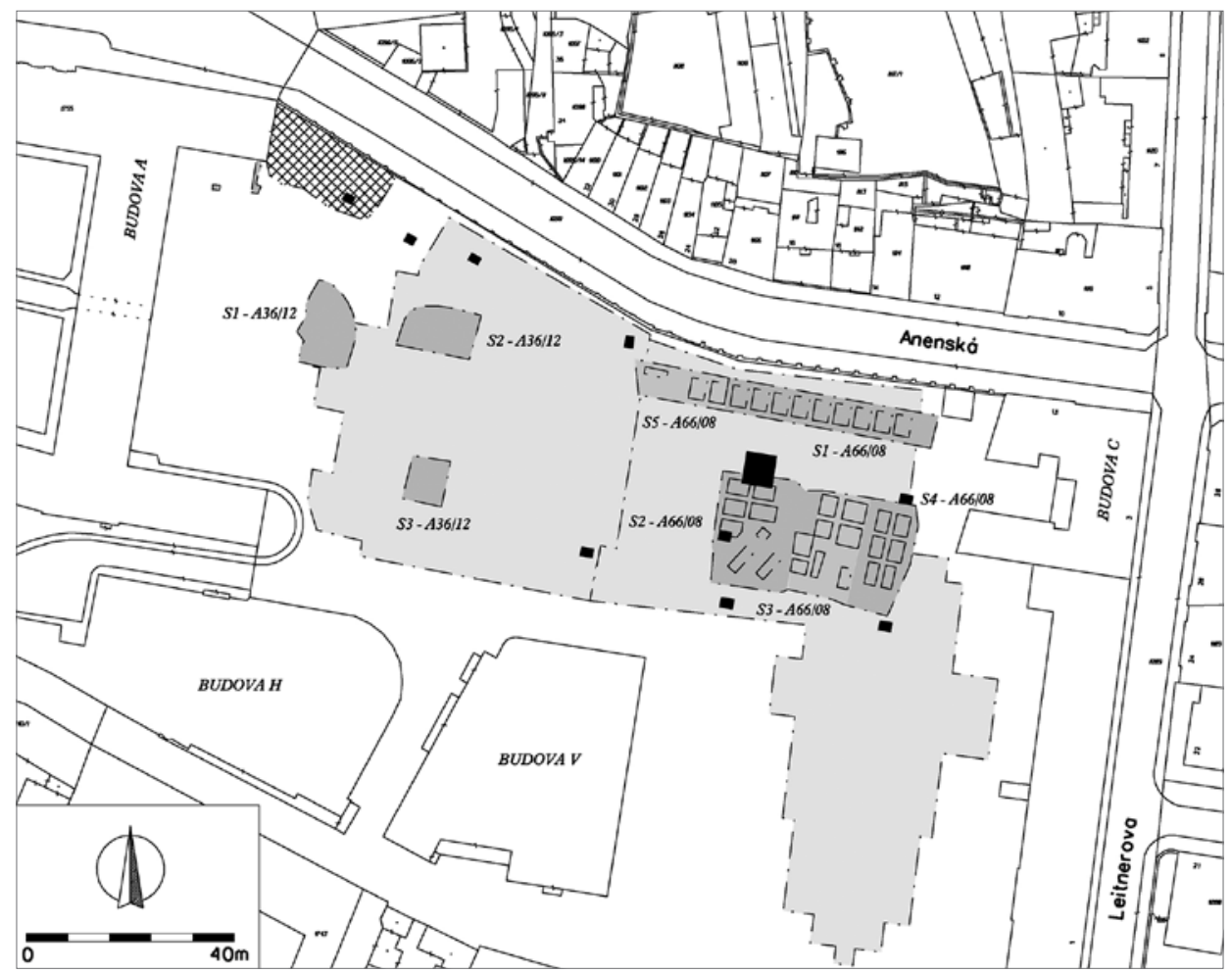

Obr. 4. Plochy archeologického výzkumu. Světle šedá - plocha stavební jámy; středně a tmavě šedá - plochy (sondy) výzkumů A66/2008, A36/2012; černě - zjišt’ovací sondy akce A106/2006; šrafura - výzkum A1/2007.

Abb. 4. Fläche der archäologischen Grabung. Hellgrau - Fläche der Baugrube; mittel- und dunkelgrau - Flächen (Sondierschnitte) der Grabungen A66/2008, A36/2012; schwarz - Sondierschnitte der Grabung A106/2006; schraffiert - Grabung A1/2007.

zvířecí kosti, zlomky skleněných nádob a železných předmětů (většinou hřebíky či přesněji neidentifikovatelné fragmenty) a předměty z barevných kovů (např. knoflíky, 2 knižní kování, 2 přezky, nábojnice, prstýnek, klička pípy). Součástí kolekce je 14 mincí. Nejstarší ražbu představuje parvus Václava II. z let 1300 až 1305, nejmladšími mincemi jsou krejcary Františka II. po roce $1800 .^{3}$

\section{Shrnutí nálezové situace}

\section{Náplavové souvrství}

Stratigraficky nejstarší část terénu, která byla zkoumána, představovalo náplavové souvrství. V obecném pohledu ho bylo možné rozčlenit na tři základní úrovně. Spodní byla tvořena vrstvou rezavě okrového písku (povrch v úrovni 197,0 až 198,0 m n.m.). Následovala tmavá modrošedá vrstva hlinitého písku (povrch v úrovni 198,2 až 198,8 m n.m.). Na něm bylo uloženo souvrství hnědošedé písčité hlíny / hlinitého písku (povrch v úrovni okolo 200,0 m n.m.). V jihovýchodní části stavební jámy bylo na druhé úrovni uloženo souvrství, jehož dominantní hmotou byl šedý jemný hlinitý písek. Proložena byla vrstvičkami hrubšího písku a výrazně byla

3 Určení mincí provedl Mgr. Kamil Smíšek - z výzkumu A36/2012 doposud předběžně, z akce A66/2008 včetně odborného posudku (Smíšek 2009). 


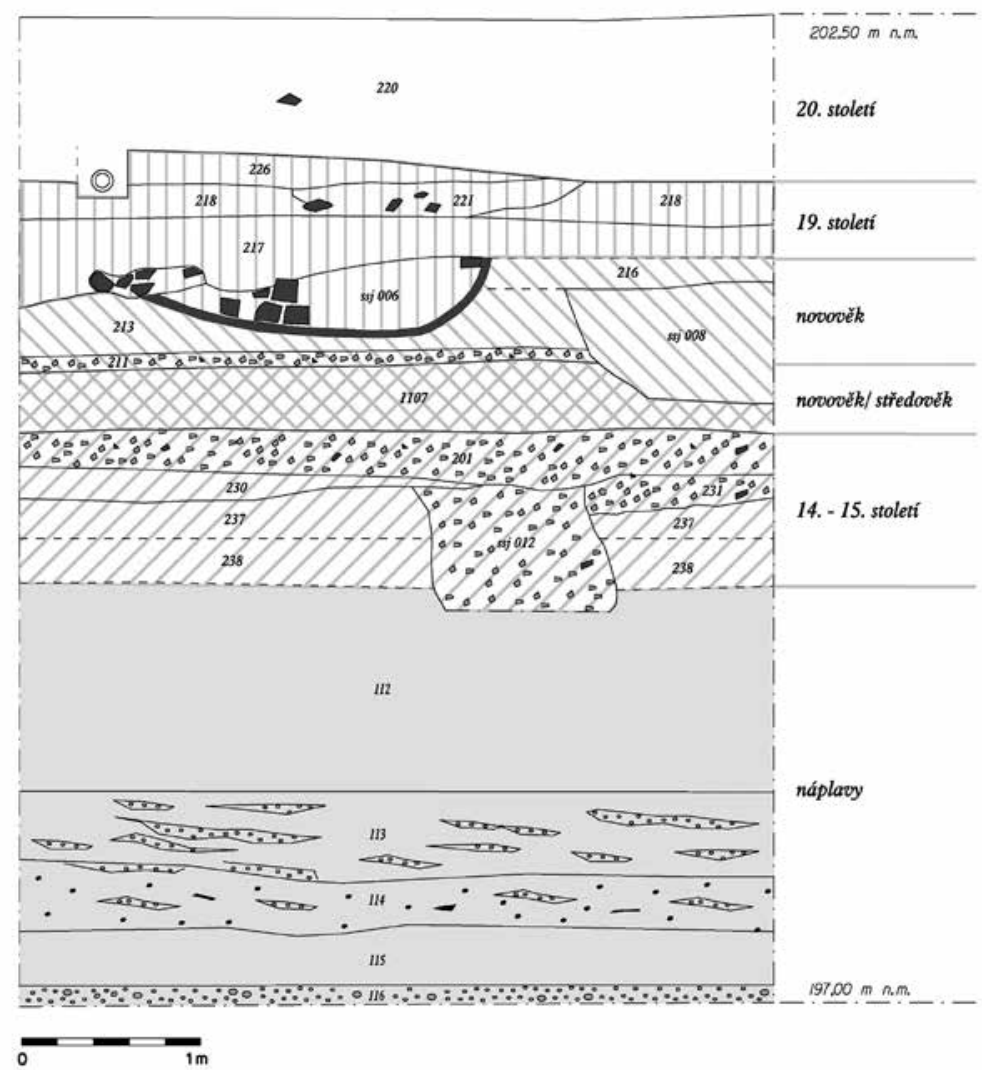

Obr. 5. Skladba terénu na složeném řezu (použity trři vybrané profily z východní části stavební jámy). 116 - rezavě okrový písek; 115 - tmavý modrošedý hlinitý písek; 113, 114 - zřejmě nánosy v korytě vodoteče (registrovány pouze v jihovýchodní části stavební jámy); 112 - šedé hlinitopísčité náplavové souvrství; 237, 238 - jeho „zkulturněná“ část; 230 - náplava; 201, 211, 231 - štěrkovo-kamenité vrstvy; 1107 - „zkulturněná“ náplava (zahradní horizont); 213, 216, 217 - šedá písčitá vrstva, členit do úrovní ji bylo možné jen na základě přítomnosti výkopových aktivit (snad náplavového původu); 218, 220, 221, 226 - navážky; s. s. j. 008, 012 - jámy neznámé funkce; s. s. j. 006 - pec.

Abb. 5. Geländezusammensetzung im zusammengefügten Schnitt (unter Heranziehung von drei ausgewählten Profilen aus dem Ostteil der Baugrube). 116 - rostockerfarbener Sand; 115 - dunkelblaugrauer lehmhaltiger Sand; 113, 114 - offenbar Ablagerung im Bett des Wasserlaufs (nur im Südostteil der Baugrube registriert); 112 - graue Lehm-Sand-Schwemmschichtenfolge; 237, 238 - sein „kulturierter“ Teil; 230 - Schwemmablagerungen; 201, 211, 231 - schotter-steinhaltige Schichten; 1107 - „kulturierte“ Schwemmablagerungen (Gartenhorizont); 213, 216, 217 - graue sandige Schicht, sie konnte nur aufgrund des Vorhandenseins von Aushubaktivitäten höhenmäßig gegliedert werden (wahrscheinlich von Schwemmablagerungen stammend); 218, 220, 221, 226 - Aufschüttungen; stratigraphischer Verband 008, 012 - Gruben von unbekannter Funktion; stratigraphischer Verband 006 - Ofen.

zastoupena organická složka (zlomky dřev apod.). Tyto uloženiny lze interpretovat jako nánosy v korytě vodoteče (zřejmě vedlejšího ramene Svratky), jejíž průběh se mohl v průběhu doby proměňovat a definitivně se usadit (či být zregulován) v podobě Svrateckého náhonu, jehož historicky zaznamenaný průběh byl posunut dále jižním směrem (v těsném sousedství stavební jámy - viz obr. 6).

Při archeologickém výzkumu byl kladen důraz především na svrchní část náplavového souvrství. Mocnost činila přibližně $1,2 \mathrm{~m}$. Jeho dominantní složkou byly jemné sedimenty hlinitých písků a písčitých hlín. Většinou nebylo pozorováno výraznější zvrstvení. Obsahovalo možnou (uhlíky, zvíŕecí kosti, zlomky vypálené hlíny / mazanice?), ale také zcela jednoznačnou 


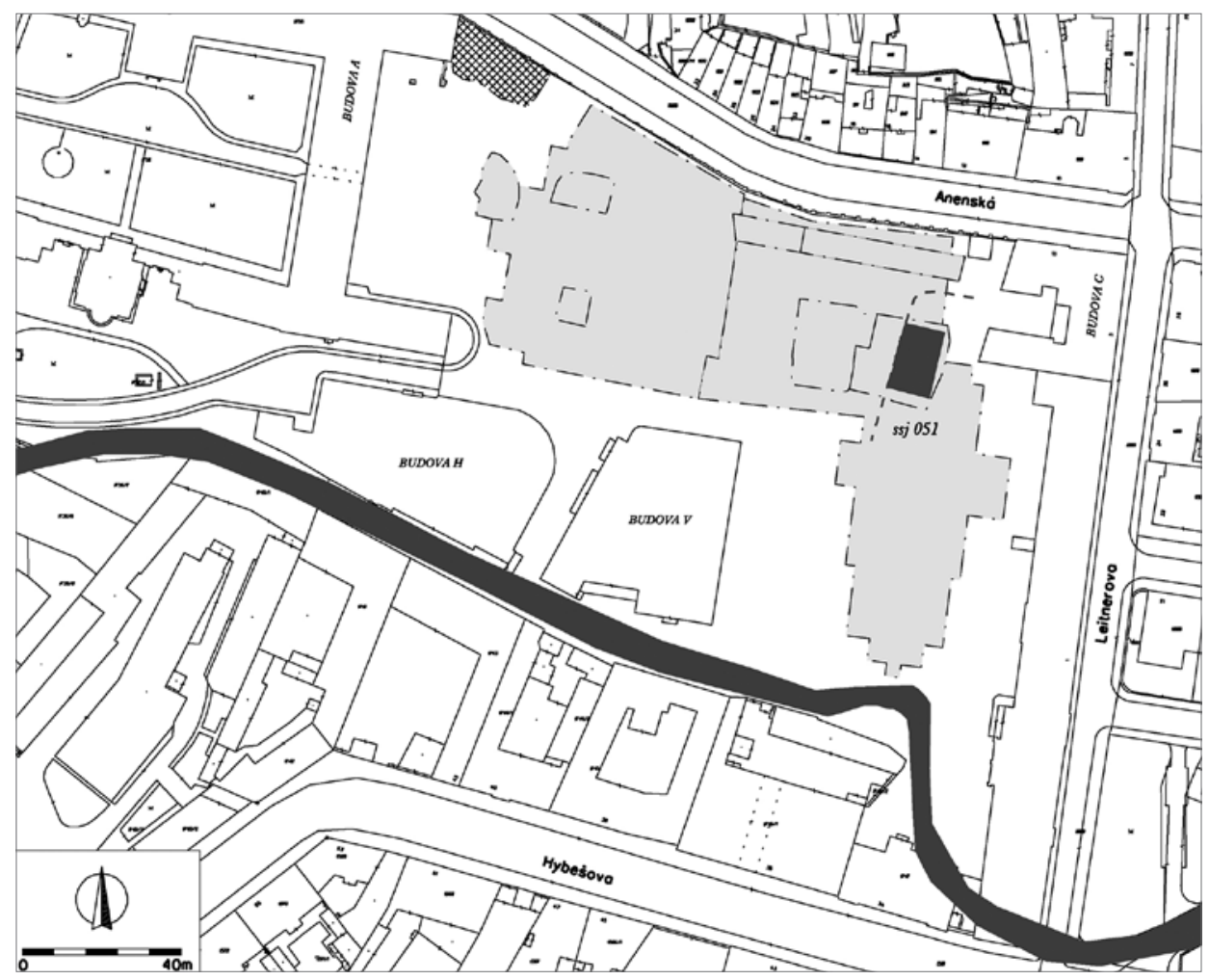

Obr. 6. Tmavě šedou barvou znázorněn tok Svrateckého náhonu (podle plánů z 19. století) a zkoumaná partie vodní nádrže (rybníku?) s. s. j. 051. Světle šedou barvou vyplněn půdorys stavební jámy.

Abb. 6. Mit dunkelgrauer Farbe wird der Lauf des Schwarza-Mühlgrabens (gemäß Plänen aus dem 19. Jhdt.) und die untersuchte Partie des Wasserreservoirs (Fischteichs?) stratigraphischer Verband 051 veranschaulicht. Hellgrau gefült ist der Grundriss der Baugrube.

(fragmenty keramických nádob) antropogenní příměs. Zčásti asi byla již původní příměsí uloženou společně se sedimenty, zčásti však zřejmě byla výsledkem dodatečného „zkulturněni““ vrstev lidskou činností přímo na lokalitě (zemědělství apod.). Byla zjišsěna obecná tendence ubývání prríměsí s rostoucí hloubkou. Získané zlomky keramiky byly datovány do středověku. Velká část zkoumaného souvrství byla asi uložena právě v tomto období. Výrazně se tedy ještě v této době projevovala akumulační činnost vedlejšího ramene řeky Svratky. Otázkou je prŕípadný podíl možného př́sunu materiálu ze svahů špilberského kopce v době silných deštůn. Závěry archeologického výzkumu v interpretaci zmíněného souvrství potvrdilo místní šetření přizvaného geologa (Mgr. A. Bajer, Ph.D., z Mendelovy zemědělské a lesnické univerzity v Brně). Stejně se vyjádřila geologická zpráva vypracovaná při realizaci zjištovacích sond v letech 2006 až 2007 (akce č. A106/2006 - Lisá-Bajer 2007).

\section{Obdobi 14.-15. století}

Poměrně výrazně ,zkulturněná“ nejsvrchnější část náplavového souvrství obsahovala zlomky keramiky ze 14.-15. století. Lze v tom spatřovat doklad využívání prostoru již během nejstaršího období existence kláštera dominikánek u sv. Anny. Lidské aktivity se v této době zintenzivnily. Jako př́iklad je možné uvést popis stratigrafického vývoje terénu ve východní 
části zkoumané plochy (akce č. A66/2008). V západní části sondy S2 byla do povrchu souvrství zahloubena drobná sloupová jamka s. j. 506 a jamka neznámé funkce s. s. j. 044. ${ }^{4}$ Zaznamenána zde byla štěrkovo-kamenitá vrstva, snad sloužící jako štětová úroveň (s. j. 231-257). Zahloubena do ní byla jáma neznámé funkce s. s. j. 012. Po zasypání uvedených výkopů se v prostoru sondy S2 a západní části sondy S3 uložila vrstva, kterou lze považovat za náplavovou (s. j. 230-376). Byla však výrazně ,zkulturněna“ především prostřednictvím malých zlomků vypálené hlíny či mazanice. Do této vrstvy byly zahloubeny jámy neznámé funkce s. s. j. 013 a s. s. j. 018. Překryla je uloženina, kterou je opět možné označit za náplavovou a následně „zkulturněnou“ vrstvu. Na rozhraní sond S2 a S3 byla do ní zahloubena jáma neznámé funkce s. s. j. 043. Po jejím zaplnění následovala výrazná štěrkovo-kamenitá vrstva zaznamenaná na celé ploše sondy S2 a západní části sondy S3 (s. j. 201-1226). Mohla sloužit jako štětová úroveň zpevňující povrch naplaveného terénu. Překryla ji vrstva, která byla svým charakterem velice podobná náplavovému souvrství (s. j. 210-289). Měla průměrnou mocnost $0,4 \mathrm{~m}$. Nejméně dvě fáze ukládání potvrdila situace v západní části sondy S2, kde se mezi horní a dolní část ,vklínily“ vrstvy spíše navážkové povahy (s. j. 204-285 a s. j. 203-284). Ve východní části sondy S1 byla mezi dvěma úrovněmi vrstvy rozlišena jamka neznámé funkce s. s. j. 028. Většina keramického materiálu, který byl z vrstvy získán, pochází ze 14.-15. století. Přítomny však byly také fragmenty novověké keramiky. Situaci je možné vyhodnotit různě. Pravděpodobná je hypotéza, že v případě zmíněné vrstvy nešlo o navážku, ale o postupně vzniklý náplavový nános. Uložil se snad ještě ve 14.-15. století či v období bezprostředně následujícím. Výrazně novověkou příměs lze považovat za výsledek následného „zkulturnění“ zř̌ejmě hlavně v důsledku zemědělské činnosti. Jejím prostřednictvím dosáhl dosavadní nárůst terénu průměrné úrovně $200,7 \mathrm{~m} \mathrm{n.m.}$

Popsané situace je možné rozčlenit do čtyř základních kategorií, ve kterých se odráží rozdílné příčiny jejich původu. Do první náleží vrstvy určené jako náplavové. Jsou důkazem, že území bylo i v této době zaplavováno vodou ze Svrateckého náhonu a lidské aktivity byly opakovaně překryty hlinitou naplaveninou. Jejich výsledkem jsou zmíněné štěrkovo-kamenité vrstvy (s. j. 231-257 a 201-1226). Jejich dominantní složkou byly kamínky a kameny. Šlo o místní surovinu (metabazit), která mohla být těžena na svazích Špilberku a Petrova. Nahodile byly zastoupeny zlomky keramických nádob, stavební keramiky a zvířecích kostí. Vrstvy zřejmě zpevňovaly povrch naplavenin a umožňovaly snadnější pohyb v zamokřeném terénu. V nejstarším období byly zaznamenány pouze na několika místech (v síle 0,05 až $0,3 \mathrm{~m}$ ), ve druhé fázi se však již jednalo o výrazné navýšení $(0,1$ až $0,5 \mathrm{~m})$ a pokrytí poměrně rozsáhlého prostoru (celá plocha sondy S2 a západní části S3 - více než $420 \mathrm{~m}^{2}$ ). Tyto navážky ovšem „znehodnocovaly“ terén pro prŕípadné využití plochy jako orných polí, zahrádek či louky. Nevylučovaly by ovšem výsadbu stromů. Nepodařilo se prokázat, že by kamenité vrstvy tvořily konstrukční bázi cest nebo byly vázány na nějaké objekty (stavby apod.).

Další kategorií antropogenních situací byly zahloubené aktivity. Registrována byla jedna drobná sloupová jamka a osm výkopů neurčené funkce. Čtyři z nich byly nevýrazné, mělké, mísovitého tvaru. Nebylo vyloučeno, že mohlo jít spíše o terénní „deprese“. Jedna byla vyplněna žlutým pískem (s. s. j. 013), jedna uloženinou náplavového charakteru s příměsí zlomků vypálené mazanice / hlíny a kamenů (s. s. j. 055) a dvě štěrkovo-kamenitou složkou (s. s. j. 028, 044). Ostatní čtyřri však již byly nepopiratelně výsledkem lidské práce (s. s. j. 012 - obdélný půdorys o rozměrech $1 \times>1,3 \mathrm{~m}$, hloubka přesahující $0,7 \mathrm{~m}$, př́ímé, svislé či mírně podhloubené stěny, štěrkovo-kamenitá výplň; s. s. j. 018 - čtvercový půdorys o rozměrech o straně $1,6 \mathrm{~m}$, hloubka přesahující $0,7 \mathrm{~m}$, přímé, šikmé, stupňovité stěny, štěrkovo-kamenitá výplň; s. s. j. 020 - oválný půdorys o rozměrech $1,25 \times 0,85 \mathrm{~m}$, hloubka přesahující $0,25 \mathrm{~m}$, konvexní, šikmé stěny, do plochého dna zahloubena drobná kůlová jamka, vyplněná šedou písčitou hlínou; s. s. j. 043 - rozsáhlá jáma o rozměrech $7 \times>7,5 \mathrm{~m}$ a maximální hloubce $0,4 \mathrm{~m}$ s konvexními, šikmými stěnami a plochým dnem, vyplněná hnědošedým pískem).

4 S. s. j. - svazek stratigrafických jednotek. Podle užité metodiky zahrnuje jeden svazek aktivity, které spolu souvisejí a často vytvářejí vyšší celek. Pro jednotlivé aktivity se užívá termín stratigrafická jednotka (zkratka s. j.). 
Zástupcem čtvrté kategorie byla vrstva s. j. 230-376, která stojí poněkud na pomezí. Svým původem byla zřejmě náplavová, byla však výrazně „zkulturněna“ především prostřrednictvím malých zlomků vypálené hlíny či mazanice. Tuto skutečnost je možné vysvětlit fragmentarizací a redistribucí materiálu z požárové destrukce nějaké nedaleké stavby. Pravděpodobnější je však hypotéza, že zmíněné zlomky by mohly mít původ v nějaké výrobní činnosti. Její konkrétní představitele (např. pece) však výzkum neobjevil. Mohou se snad nacházet v blízkém sousedství jižně od stavební jámy. Svou polohou u vodního zdroje mohl být daný prostor pro některé výrobní provozy výhodný.

\section{Období novověku}

Dokladů lidské činnosti v tomto období výrazně přibývá. Tato skutečnost nemusí být interpretována pouze jako důkaz zintenzivnění aktivit $\mathrm{v}$ tomto prostoru. Zřejmě se zde odráží také jejich rozmanitost a především schopnost projevit se $\mathrm{v}$ archeologickém terénu. Zcela jednoznačnými a výraznými projevy jsou v tomto ohledu výkopové aktivity. Nejstarší z nich byly zahloubeny do povrchu vrstvy s. j. 210-289, která byla zařazena ještě do období 14.-15. století, mohla však alespoň částečně vznikat (rozhodně byla ovlivňována) ještě v mladším období. Výkopové aktivity vznikají postupně po celé období, čehož dokladem byly stratigrafické situace prokazující hloubení jam z různých úrovní terénu, který se postupně navyšoval. Mobiliář získaný z výplní výkopů lze ve většině případů datovat do období druhé poloviny 17 . a 18. století. Celkem bylo zaznamenáno dvacet výkopových aktivit. Všechny se nacházely ve východní části stavební jámy (především v prostoru sond S2 a S3), v západní části zkoumané plochy byla dokumentována pouze jedna jáma v sondě S2. Dva výkopy byly determinovány jako sloupové jamky, funkce dalších šestnácti nebyla bliže určena. Většinou se jednalo o poměrně nevýrazné, ničím jednoznačně nespecifické výkopy menších a středních rozměrů, často o malé hloubce. $Z$ průměru vystupovalo pouze pět výjimek: s. s. j. 008 - obdélná jáma o rozměrech $2,3 \times$ ca $6 \mathrm{~m}$ a hloubce $0,5 \mathrm{~m}$ se šikmými stěnami a plochým dnem; s. s. j. 014 - pravděpodobně velká jáma neznámého půdorysu o hloubce $1,4 \mathrm{~m}$; s. s. j. 024 - segment lineárního žlábku široký 0,4 a hluboký $0,2 \mathrm{~m}$; s. s. j. 029 - jáma neznámého půdorysu o hloubce $0,6 \mathrm{~m}$ se šikmými stěnami a plochým dnem; s. s. j. 041 - pravděpodobně jáma obdobného charakteru jako s. s. j. 008, nebyla však blíže zkoumána. Do jisté míry zajímavou byla skutečnost, že výplň sedmi jam tvořil žlutý jemný písek.

V sondě S5 byla dokumentována pec s předpecní jámou (s. s. j. 001). V zachovaném reliktu bylo vlastní těleso pece zahloubeno $0,26 \mathrm{~m}$ do terénu. Půdorys byl kruhový, v úrovni dna pece o průměru $0,9 \mathrm{~m}$. Zachované partie stěn byly podhloubené, takže lze usuzovat na kupolovitý tvar pece. Není možné zcela vyloučit, že těleso pece mohlo být zčásti nadzemní. Stěny i dno byly propálené v maximální síle $0,1 \mathrm{~m}$. Dno překrývala vrstvička popela. Ústí do předpecní jámy, které se připojovalo z jižní strany, bylo zpevněno na každé straně jednou na výšku postavenou cihlou. Výplň tvořila uloženina obdobného charakteru jako okolní terén. Stratigrafická situace a získané nálezy dovolují pec datovat do druhé poloviny 17. a 18. století. Její fungování můžeme spojovat s nějakým potravinářským provozem. Pec obdobného charakteru zařazená do stejného období byla dokumentována $20 \mathrm{~m}$ jihovýchodním směrem jednou ze zjištovacích sond $\mathrm{z}$ roku 2006 (Holub a kol. 2007, 445; Peška 2007, viz sonda S10).

Ojedinělou a naprosto specifickou záležitostí byla rozsáhlá výkopová aktivita s. s. j. 051. Zabírala celou plochu sondy S4 a nejvýchodnější partii sondy S3 (obr. 6). Půdorys zůstal neznámý. Hloubka dosahovala v průměru $1 \mathrm{~m}$. Zachycena byla část šikmé západní stěny. Na plochém dně ležela ulehlá tmavě černohnědá až kaštanově hnědá organická vrstva o síle $5 \mathrm{~cm}$. Její dominantní složkou byla amorfní a strukturovaná rašelina. Především na jejím základě byla výkopová aktivita určena jako vodní nádrž. Stejně se vyjádřil geologický posudek mikromorfologických vzorků, které byly odebrány v roce $2006 \mathrm{v}$ jedné ze zjišt’ovacích sond, která situaci rovněž dokumentovala (Lisá-Bajer 2007). S největší pravděpodobností by mohlo jít o rybník. Zcela jasně byl prokázán na ploše $180 \mathrm{~m}^{2}(17 \times 10,6 \mathrm{~m})$. Vzniknout mohl teoreticky již v období středověku, spíše je však novověkého stárí. Vyloučit však nelze staršího předchůdce. Zasypán byl 
štěrkovo-kamenitými uloženinami, ze kterých byl získán archeologický materiál datovatelný do období druhé poloviny 17. a 18. století.

Se zasypáním nádrže souviselo překrytí terénu ve východní části zkoumané plochy štěrkovo-kamenitou vrstvou $(0,05-0,15 \mathrm{~m})$. Místy na ní byla uložena vrstvička jemného žlutého písku (ca $0,1 \mathrm{~m}$ ). K výraznějšímu navýšení terénu došlo až prostřednictvím šedé písčité vrstvy s. j. 213-1206 o mocnosti $0,6 \mathrm{~m}$. Jevila se jako jednolitá, pouze na základě př́tomnosti výkopů ji bylo možné rozdělit do tř́ úrovní. První lze zařadit do období druhé poloviny 17. a 18. století, druhou do 18 ., 19. století a třetí do 19. století. Otázkou je její původ. Snad by se mohlo stále jednat o postupný výsledek akumulace v době záplav a jeho následného „zkulturňování“. Jinak by bylo nutné uvažovat o postupném zvyšování navážkovou činností.

\section{8.-20. století}

Většina situací z tohoto období pochází pravděpodobně z 19. století. Delší časové rozmezí bylo stanoveno především $\mathrm{z}$ důvodu nejednoznačného datování některých aktivit, které mohly být na základě získaných poznatků datovány pouze v rozsahu 18.-19. století a 19.-20. století. Tyto situace jsou již odrazem dějů spojených nejprve s císařsko-královským zaopatřovacím ústavem a následně zemskou nemocnicí.

Lidská činnost se v archeologickém terénu výrazně projevila především výkopovými aktivitami. Celkem jich bylo zaznamenáno třicet čtyři. Většina se nacházela opět ve východní části stavební jámy. Tř́i výkopy byly determinovány jako sloupové jamky, funkce ostatních nebyla většinou blíže určena. Nutno dodat, že velká část byla dokumentována pouze na profilech. Šlo o širokou škálu jam rozmanitých charakterů. Výraznějším př́ípadem byla snad pouze jáma s. s. j. 017 - zřejmě větší, o hloubce minimálně $0,3 \mathrm{~m}, \mathrm{~s}$ šikmými stěnami a plochým dnem, do něhož byla ve zkoumaném segmentu vyhloubena jáma a do ní usazen dřevěný sloup. Jednoznačně rozpoznatelnými byly relikty dvou zahloubených pecí. Jedna byla dokumentována na rozhraní sond S2 a S3 (s. s. j. 006), druhá v západní části sondy S1 (s. s. j. 010).

Zachovalý relikt pece s. s. j. 006 byl zahlouben $0,3 \mathrm{~m}$ do terénu. V této úrovni měl vnitřní prostor půdorys pravoúhlého lichoběžníku o délce základny $2,2 \mathrm{~m}$ a výšce $0,85 \mathrm{~m}$. Stěny byly vyzděny z cihel pojených hlínou. Síla vyzdívky činila bud' 6,5 nebo $14,5 \mathrm{~cm}$. V delší ose byl uvnitř pece převážně z cihel rovněž pojených hlínou vyzděn sokl o síle 16 až $18 \mathrm{~cm}$, dosahující výšky dochované koruny stěn pece. Nebyl dotažen až k jižní stěně pece a ve dvou úsecích (18 a $26 \mathrm{~cm})$ byl přerušen. Dno bylo propáleno v průměrné síle $0,1 \mathrm{~m}$. Ze severní strany se k rameni lichoběžníku (pece), totožnému s jeho výškou, přimykalo předpecí. Představovala ho mísovitá jáma oválného půdorysu o rozměrech 1,6 × $0,9 \mathrm{~m}$. Její delší osa byla kolmá na delší osu pece. Západní stěna víceméně navazovala na průběh západní stěny pece, východní byla tudíž odsazena o $0,7 \mathrm{~m}$. Tento úsek (vlastně jižní stěna předpecí) byl vyzděn, stejně jako pec. Předpecní jáma i pec byly z převážné části vyplněny zlomky cihel a střešních tašek a vypálenou hlínou. Šlo zřejmě o části konstrukce pece. V zásypu pece na samotném dně byly nalezeny čtyři železné nástroje (lopata, rýč a dvě motyky). Na základě celkové terénní situace je možné prohlásit, že vyšší nedochovaná úroveň konstrukce pece byla nadzemní. Podle získaného keramického materiálu a především podle kolkovaných cihel náleží pec do 19. století, spíše do jeho druhé poloviny. Zcela nelze vyloučit možnost, že dokumentovaná situace mohla být jen reliktem objektu, jehož součástí byla stejná situace (zrcadlově obrácená), napojená ze západní strany, kde byl terén zničen.

Z otopného zařízení s. s. j. 010 se zachovala jen propálená úroveň dna s popelovitými vrstvičkami. Složitější konstrukci snad naznačovaly přítomné cihly a zlomky střešních tašek. Dokumentovaný zbytek byl zahlouben $0,1 \mathrm{~m}$ do terénu. Ke tvaru a funkci otopného zařízení není ze zachycené situace možné se přesněji vyjádřit. Jeho šiřka snad činila $0,8 \mathrm{~m}$, maximální délka propálené úrovně dosahovala $2,5 \mathrm{~m}$. Zda by pozůstatkem jejího předpecí mohla být oválná jáma v těsné blízkosti jejího západního konce (s. s. j. 009), je hypotetickou otázkou. Zničená terénní situace neposkytla jednoznačnou odpověd'. Výrazný podíl ve výplni jámy představovaly cihly a jejich zlomky. Snad by mohly pocházet ze zbourané konstrukce pece. Přesné datování otopného zařízení nebylo možné na základě terénní situace určit. Zařazeno bylo do období 18.-19. století. 
Samostatnou skupinou byly liniové výkopy, které lze považovat za žlaby či prŕikopy. Tři byly dokumentovány ve východní části zkoumané plochy (sondy S3 a S4), další tři v západní. Jejich linie probíhaly ve směru sever-jih. Pouze jeden ze žlábků ve východní části měl osu orientovanou ve směru západ-východ (s. s. j. 007). Výkopy ve východní části stavební jámy měly poněkud subtilnější charakter. Maximální šířka dosahovala $0,9 \mathrm{~m}$, hloubka se pohybovala od 0,2 do $0,4 \mathrm{~m}$. Průřez byl mísovitý. Dva z nich probíhaly paralelně vedle sebe ve vzdálenosti $1 \mathrm{~m}$ (s. s. j. 021 a 025). Výkopy 007 a 025 byly vyplněny žlutým pískem, ve výplni žlábku s. s. j. 021 měla výrazný podíl maltovina, zlomky stavební keramiky a fragmenty keramických nádob. Liniové výkopy v západní části byly odlišného charakteru. Dva výkopy, které v sondě S1 probíhaly paralelně vedle sebe ve vzdálenosti $2,6 \mathrm{~m}$, měly lichoběžníkový průřez, hloubka činila $0,6-0,7 \mathrm{~m}$. Jeden byl široký $2,1 \mathrm{~m}$ a druhý $1,5 \mathrm{~m}$ (s. s. j. 002 a 003 ). Zasypány byly stavební sutí. Výkop, jehož segmenty byly dokumentovány v sondě S2 a S3 (s. s. j. 007=008), měl mísovitý průřez, hloubka přesahovala $0,6 \mathrm{~m}$ a dokumentovaná šiřka činila $1,7 \mathrm{~m}$. V dolní části výkop vyplňovala uloženina, kterou lze interpretovat tak, že zanášela dno v souvislosti s nějakým vodním režimem. Následně došlo k zasypání, v rámci sondy S3 opět převážně stavební sutí. Archeologický materiál, který byl ze zásypů vyzvednut, je možné datovat do 19. století. Na základě srovnání s plánem z roku 1822 lze výkop ztotožnit s jedním z liniových útvarů, které jsou na něm zobrazeny a vyúst'ují do koryta Svrateckého náhonu (obr. 7). Zřejmě se podílel na zajištění vodního režimu, který fungoval v parku zaopatřovacího ústavu. Je otázkou, zda za

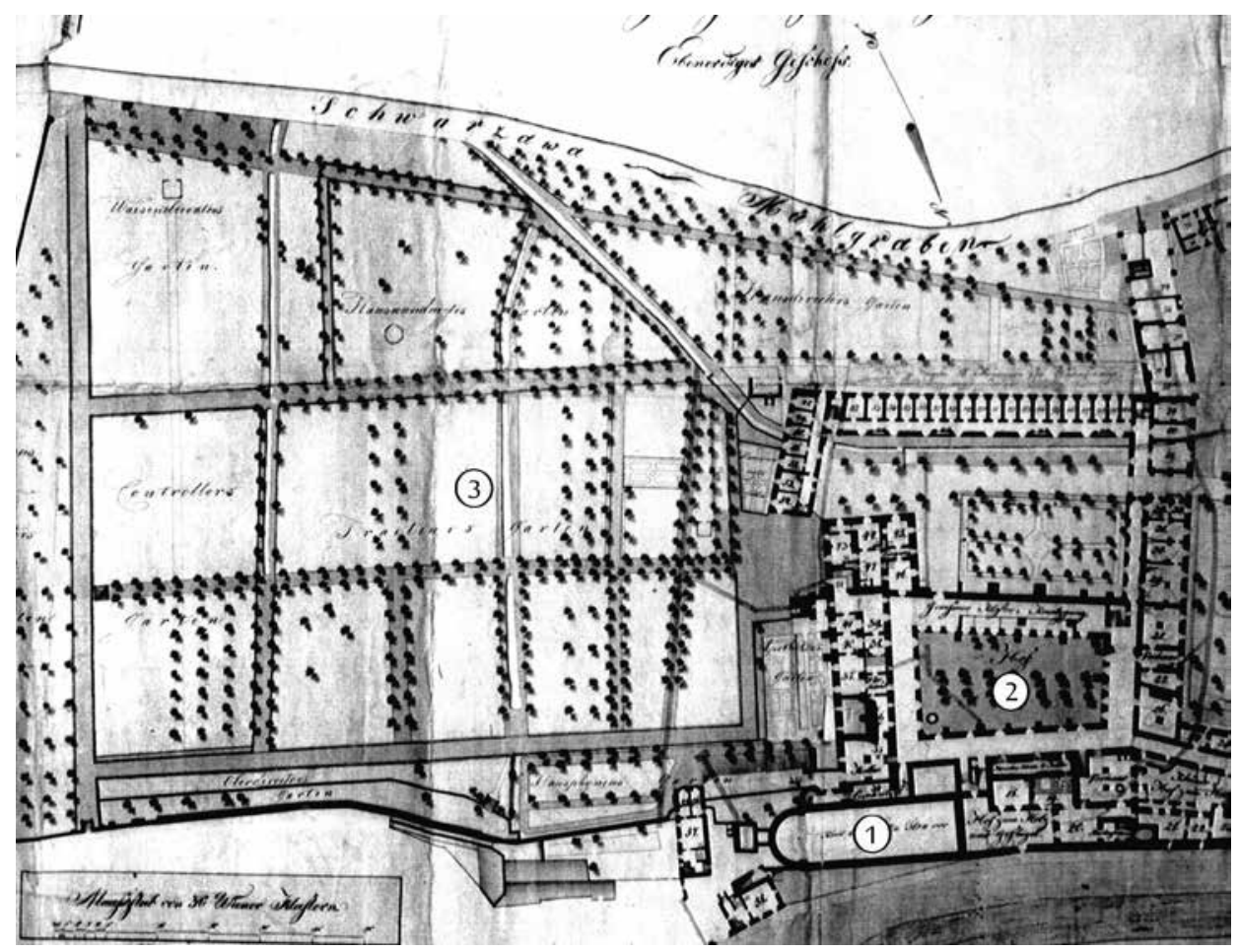

Obr. 7. Výřez plánu z roku 1822 (Archiv města Brna, fond U9). Orientován k jihu. 1 - kostel sv. Anny; 2 - budovy někdejšího kláštera; 3 - liniový útvar, který lze ztotožnit se zkoumaným příkopem s. s. j. $007=008$.

Abb. 7. Ausschnitt aus einem Plan von 1822 (Archiv der Stadt Brno, Bestand U9). Orientierung nach Süden. 1 - Kirche St. Anna; 2 - Gebäude des ehemaligen Klosters; 3 - Liniengebilde, das mit dem untersuchten Graben stratigraphischer Verband $007=008$ identifiziert werden kann. 
stejným či obdobným účelem byly vyhloubeny i ostatní popsané výkopy. „Stopy vody“ u nich nebyly jednoznačně patrné, rozhodně tomu tak bylo v př́ípadě výkopů s. s. j. 002 a 003 . Možná však výkopy nestihly svůj úkol splnit.

Výsledkem lidských aktivit tohoto období byly rovněž uloženiny, které již měly zcela nepochybně navážkový charakter. V severovýchodní části zkoumané plochy byly například dokumentovány popelovité vrstvy. Skutečnost lze snad vysvětlit tak, že do prostoru mohl být postupně deponován odpad z otopných zařízení. Že zahrada sloužila také k ukládání odpadu, dokládají výplně některých jam. Přesný účel jejich vyhloubení sice neznáme, druhotně však posloužily k uložení již nepotřebné kuchyňské keramiky. Její fragmenty tvořily dominantní či výraznou složku výplně žlábku s. s. j. 021 a jam s. s. j. 052 a 053. V 19. století dosáhl povrch terénu úrovně $201,9 \mathrm{~m} \mathrm{n} . \mathrm{m}$.

\section{0. století}

Projevy aktivit tohoto období, které jsou již plně výsledkem dějů v zemské a posléze fakultní nemocnici, byly sledovány pouze okrajově. Prostřednictvím navážek dosáhl terén stávající úrovně 202,5 m n.m. Opět byly zaznamenány výkopové aktivity neznámé funkce. Zachyceny byly základy nemocničních budov, které byly asanovány během stavebních prací nebo staveb, které byly zbourány již v minulosti. Sonda S3 v západní části stavební jámy byla např́íklad usazena mezi základová zdiva starého interního pavilonu z let 1908-1909 - někdejší budovy B1. Vlastní exkavace se dotkla v rámci sondy S1 akce č. A36/2012 pouze části stavby, která stála ve východním sousedství hlavní budovy nemocnice již na konci 19. století a na počátku 20. století byla zbourána. Dokumentovaný segment představoval jeho průjezdovou partii. V úpravě jeho povrchu bylo rozpoznáno několik fází.

Z aktivit 20. století byla zvýšená pozornost věnována pouze dokumentaci zaniklých protileteckých krytů z období druhé světové války. Odhaleny byly relikty čtyř objektů (obr. 8). Jednalo se o chodbovité útvary vybudované z betonu. Strop tvořila poměrně zploštělá valená klenba. Vnitřní prostor byl vysoký $2,5 \mathrm{~m}$. Šířka chodeb činila při dně 1,2 až $1,3 \mathrm{~m}$, ve střední části okolo $2 \mathrm{~m}$. Zúžení u dna tvořilo lavicovité odsazení stěn. Vstupy byly řešeny prostřednictvím betonových schodišt'. Odvětrávání krytů zajištovalo několik betonových potrubí, vyvedených podél vnější stěny na povrch. Dva z krytů byly nalezeny ve východní části staveniště a byly původně situovány na volném prostranství mezi někdejšími budovami B2 a D (byly již publikovány - viz Holub-Merta-Zůbek 2010). Dva byly vystavěny v severním a západním sousedství někdejší budovy B1. Velká část krytů byla zplanýrována a zasypána. Pouze segment krytu zkoumaný v sondě S1 západně od budovy B1 si zachoval svoji průchodnost (obr. 9). Ze získaných poznatků je zřejmé, že kryty přečkaly druhou světovou válku a byly dále využívány. Došlo však ke zvýšení dna, takže průchodná výška činila pouze $1,6-2 \mathrm{~m}$. Vybudovány byly nové př́íčky, popř́ípadě osazení dveří. Zásypy krytů ve východní části obsahovaly poměrně velké množství zdravotnických potřeb (většinou skleničky, zkumavky, ampule apod.). Na základě tohoto nálezu se lze domnívat, že kryty byly zasypány snad v 50 . letech 20 . století. Existence krytů upadla v obecné zapomnění. Nic o nich nevěděl příslušný správce těchto objektů v nemocnici, před nímž tuto funkci vykonával ve druhé polovině 20. století jeho otec. Na vznesený dotaz o př́ípadné existenci dokumentů týkajících se krytů přišla $\mathrm{z}$ archivního oddělení nemocnice negativní odpověd'. Pouze jeden z pamětníků procházející v roce 2012 kolem výzkumu sondy S1 se upamatoval, že se jako malé dítě chodíval s rodiči při náletech schovávat $\mathrm{z}$ Mendlova náměstí do krytů v nemocnici. V jejím areálu se dnes nacházejí dva zachovalé válečné kryty, jejich prostory jsou stále využívány. Jeden se nachází v jižním sousedství kaple sv. Anny, která je součástí jižního kř́ídla hlavní budovy, druhý na volném prostranství východně od budovy I. 


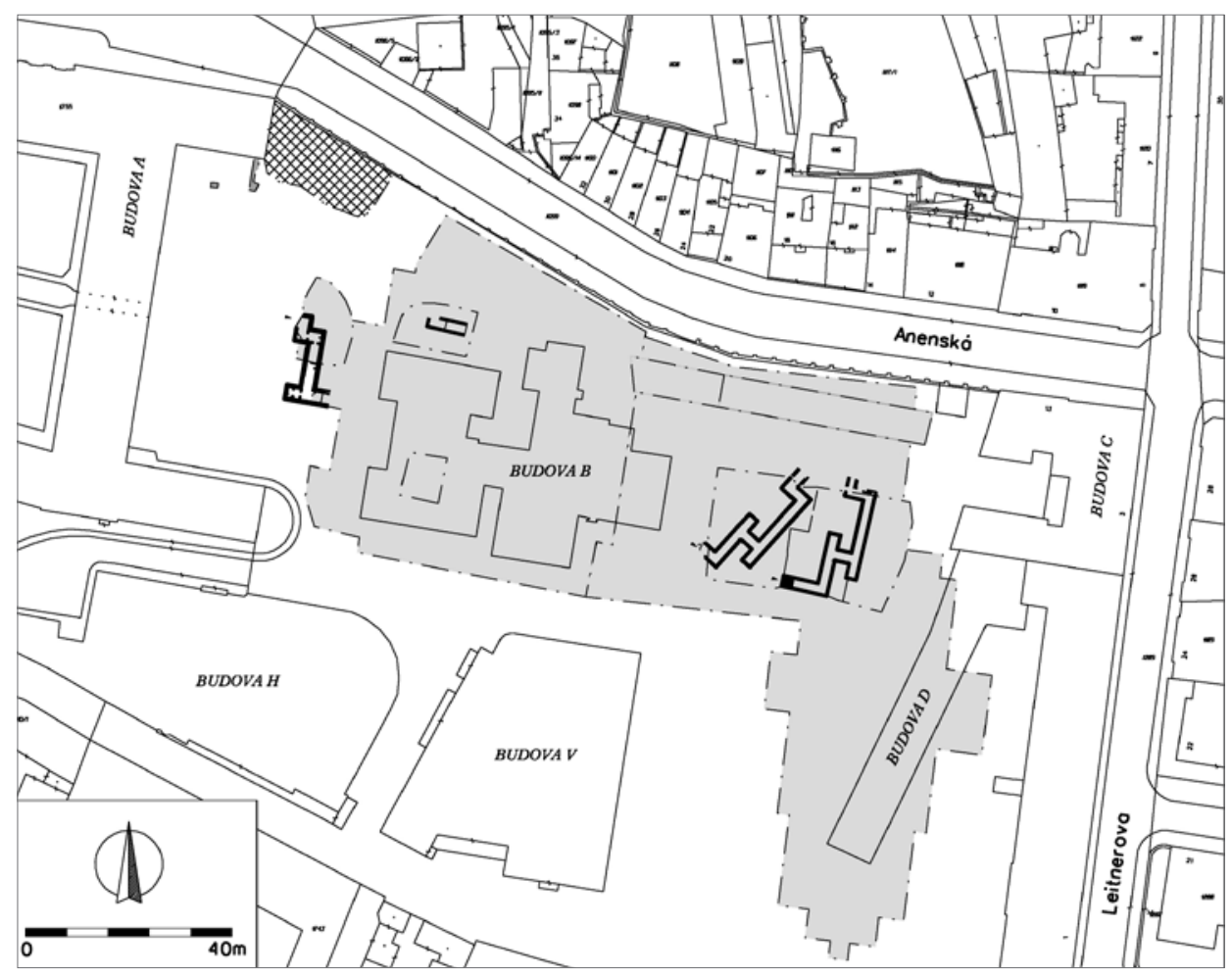

Obr. 8. Silné černé linie vyznačují zkoumané segmenty protileteckých krytů z druhé světové války. Světle šedou barvou vyplněn půdorys stavební jámy.

Abb. 8. Die stark schwarzen Linien kennzeichnen die untersuchten Segmente der Luftschutzbunker aus dem zweiten Weltkrieg. Hellgrau gefüllt ist der Grundriss der Baugrube.

\section{Závěr}

Prostor dotčený referovanými archeologickými výzkumy je ze své topografické pozice důležitým místem ve středověkých dějinách brněnského území. Ve starším období (11.-12. století) se nacházel v blízkosti někdejšího mocenského centra, od vzniku města ve 13. století byl zase součástí nejbližší předměstské struktury. Z pohledu lokálních podmínek se již tak zajímavý nemusí zdát. Místo samotné nemělo prríhodné podmínky k usídlení. Jednalo se o inundační pásmo Svrateckého náhonu. Pravděpodobně bylo zamokřeno, na čemž se mohla podílet i voda stékající ze svahů špilberského kopce, při jehož úpatí se rozkládá.

Že prostor nebyl sídelně atraktivní, potvrdily výsledky archeologických výzkumů. Nebyly zaznamenány žádné stopy lidských sídel ani v období pravěku, ani v éře středověku. Ty byly vysunuty do poloh, které tolik neohrožovaly záplavy. Na takovém místě byl vystavěn rovněž klášter dominikánek a jeho předchůdce, královský dvorec. Jejich relikty a případně projevy staršího osídlení je nutné hledat v prostoru hlavní nemocniční budovy v bezprostředním západním sousedství zkoumané plochy. Zdá se, že právě při západní hranici stavební jámy či nedaleko od ní se nacházel předěl mezi sídelně příznivějším a zaplavovaným územím. 


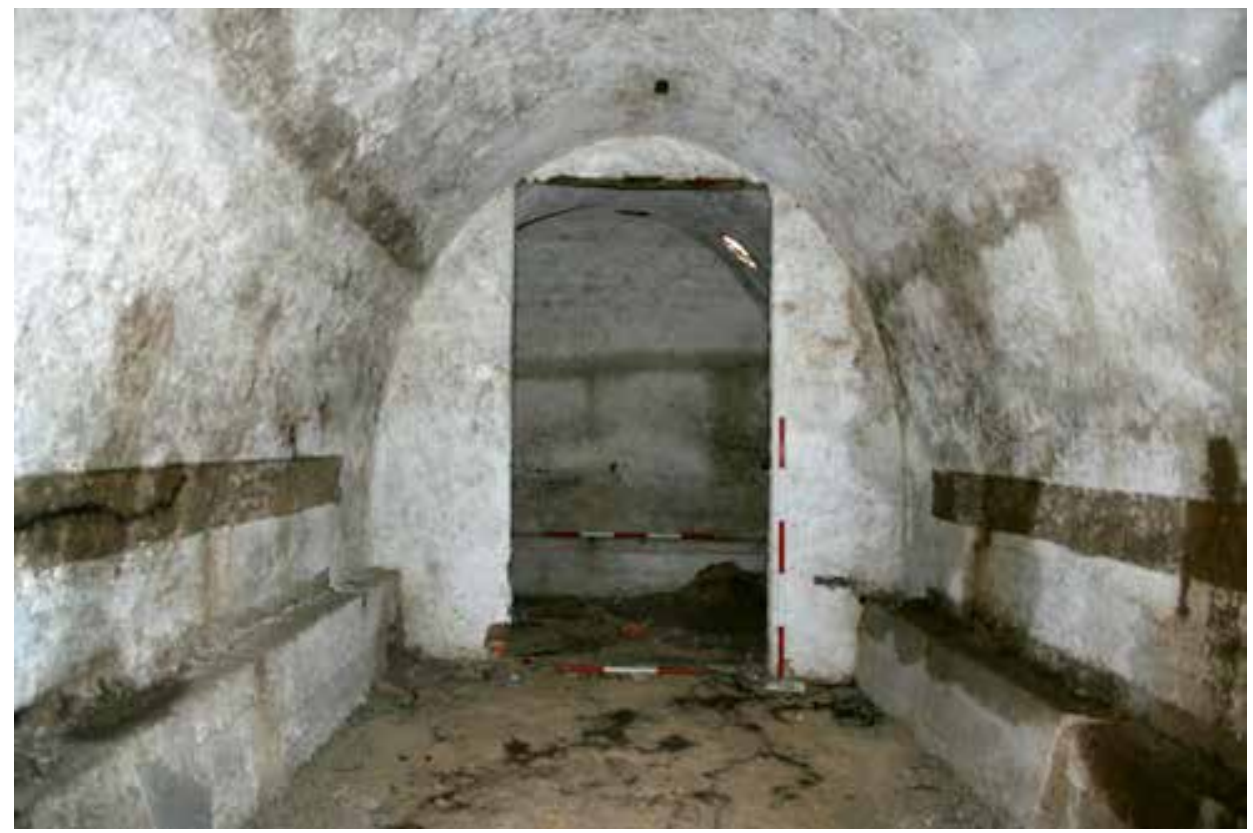

Obr. 9. Pohled od jihu na část protileteckého krytu západně od budovy B. Zdroj Fotoarchiv Archaia Brno, o. p. s. - foto č. 5485-2012.

Abb. 9. Blick von Süden auf einen Luftschutzbunkerteil westlich von Gebäude B. Quelle Fotoarchiv Archaia Brno, o. p. s. Foto Nr. 5485-2012.

Zkoumaný prostor nemusel být ponechán ladem. Byl zřejmě zemědělsky využíván. Při zaplavování území a snad často zamokřeném terénu nemusel být způsobilý k polnímu hospodářství, ale bylo jej možné využívat k výsadbě užitkových stromů. Tato skutečnost by se mohla odrážet ve výpovědi prvních písemných pramenů. V nadání kláštera z roku 1312 je vedle královského dvora zmíněn ovocný sad a zahrada, o dvoru se sadem hovoř́i také odkaz z roku 1333 (viz oddíl 2 Stručná historie kláštera). V době existence kláštera je sem umístována jeho zahrada, pro mladší období doložená ikonografickými prameny. Je však otázkou, zda tyto pozemky patřily klášteru již od jeho počátků. Po zrušení kláštera se staly zahradou zaopatřovacího ústavu a následně nemocničním parkem.

Archeologický výzkum jednoznačně prokázal, že území bylo zaplavováno po celý středověk a zřejmě i v následujícím období. Náplavová aktivita Svrateckého náhonu byla doložena rovněž na Starém Brně při výzkumech na Mendlově náměstí. Jako ochranu před nimi je možné interpretovat výrazné zvyšování terénu navážkami od 15. století (Černá-Zůbek 2012; ČernáSedláčková-Zůbek 2009; Holub a kol. 2010, 424; Černá a kol. 2013, 168). Pro nejmladší fázi (18.-19. století) nebyla výpověd' archeologických pramenů tak jednoznačná, ale pravděpodobně k záplavám stále docházelo. Bezprostřední ohrožení představoval Svratecký náhon. Je však nutné počítat také se Svratkou samou. Ještě projekt z roku 2007 (dávno po zrušení náhonu), který hodnotil rizika a navrhoval protipovodňovou ochranu, zahrnuje předmětný prostor do rozsahu rozlivu stoleté vody, který by nebyl ovlivněn nádržemi na toku řeky. Je zajímavé, že se tento vyhýbá hlavní nemocniční budově (Brázdil-Valášek-Soukalová a kol. 2010, obr. 225). Před 20. stoletím nebylo řečiště Svratky v prŕíslušném úseku výrazněji regulováno. ${ }^{5}$ Do té doby byly

5 V závěru první poloviny 19. století byla regulována pouze část toku od hornoheršpického mostu až do Vojkovic (Brázdil-Valášek-Soukalová a kol. 2010, 107-108) 
povodně na brněnském území častým jevem. Velké nebezpečí trvalo i po celé 19. století. Ve vztahu k dotčenému území lze jako příklad vyzdvihnout několik událostí. Velká povodeň, která postihla i Staré Brno, nastala v roce 1805 . V roce 1827 byl poškozen Svratecký náhon. O tři roky později bylo povodní opět zasaženo Staré Brno. V následujícím roce došlo k protržení hráze na levém břehu mlýnského náhonu. V roce 1838 vzniklo velké nebezpečí jeho rozlití (Brázdil-Valášek-Soukalová a kol. 2010, 300, 314, 320, 324, 328). Že problémy se Svrateckým náhonem přetrvávaly i v 19. století, dokazují značné výdaje, které muselo vedení nemocnice vynakládat na pravidelné čištění jeho koryta, odstraňování škod po zátopách, neustálé opravy ochranných náspů a úpravy břehů (Sajner 1986, 64).

Archeologická zjištění v klášterní zahradě nelze považovat za ohromující. Tato skutečnost je přirozeným odrazem charakteru aktivit, které se tu mohly odehrávat. Je však možné prohlásit, že zkoumané archeologické situace nebyly nevýrazné a v určitém pohledu nepostrádaly zajímavost. Dokumentována byla řada výkopových aktivit rozličného charakteru. První pocházejí ze 14. století, tedy z éry vzniku a budování kláštera. Jejich výskyt se zintenzivňuje v novověkém období a přetrvává i v době, kdy se klášterní zahrada přeměnila v nemocniční park. Přesný účel většiny z nich se nepodařilo odhalit. Bude úkolem obdobných výzkumů a srovnávacího studia dát v tomto směru uspokojivější odpověd'. Že se nejedná pouze o „bezvýznamné“ jámy, naznačuje v některých případech jejich charakter (např. rozsah, pravidelný půdorys, stopy př́itomnosti svislých dřevěných konstrukčních prvků, specifická výplň - viz např. štěrkové zásypy středověkých výkopů nebo novověké jámy vyplněné jemným žlutým pískem).

Jedním z nejvýraznějších novověkých objektů byla vodní nádrž. Mohla sloužit jako chovný rybník a zásobovat klášterní komunitu rybami. Její př́ítomnost mohla také do jisté míry přispívat k ustálení vodního režimu v daném prostoru. Do zahrady byly umístěny rovněž určité výrobní procesy. Jednoznačně to dokládají čtyři zahloubené pece. Měly různý charakter. Spojovat je lze s potravinářskou výrobou. Dvě nejstarší náležely do závěrečné etapy existence kláštera, nejmladší pec již sloužila provozu nemocnice ve druhé polovině 19 . století. ${ }^{6}$ Výzkum nepřinesl jasné doklady přítomnosti nějakých staveb. Zcela vyloučit jejich existenci (hlavně v případě „lehčích“ konstrukcí) však nelze. Zajímavým projevem bylo pokrytí velké části plochy zahrady v její východní partii štěrkovou vrstvou. Pokrytí bylo provedeno opakovaně, dvakrát během 14.15. století a jednou v období druhé poloviny 17. a 18. století. Štěrková vrstva omezila možnost prŕpadného pěstování polních plodin či pastvy. Je však otázkou, do jaké míry se tyto aktivity uplatňovaly na území ohroženém záplavami. Cílem byla zřejmě snaha zpevnit pochozí úroveň zamokřeného terénu. Není vyloučeno, že se tak dělo v souvislosti s využíváním místa k další činnosti.

Archeologické výzkumy ve východní části areálu Fakultní nemocnice u sv. Anny v Brně se odehrály na specifickém druhu lokality, kterou determinují dvě výrazné charakteristiky. Z hlediska přírodních a morfologických podmínek se jedná o inundační zamokřené území ohrožované záplavami, z hlediska historického o prostor využívaný jako klášterní zahrada a posléze nemocniční park. Svými výsledky výzkumy myslím zcela dostatečně prokázaly opodstatněnost jejich realizace, jejíž nutnost byla zpochybňována i některými hlasy z řad odborné veřejnosti se zdůvodněním, že archeologický terén sestává pouze z ,náplav a navážek“. Získané informace napomohly k poznání charakteru archeologické stopy, kterou tento druh lokality se svými procesy zanechává. Předložený text jasně dokládá, že ji nemůžeme jednoduše zúžit jen na „náplavy a navážky“. Ačkoliv se výzkum realizoval na méně atraktivním místě (např̀. ve srovnání s vlastním klášterem či případným hradem brněnských knížat), jeho poznatky přispěly do postupného sestavování mozaiky historicko-topografického vývoje brněnského území.

6 Pece byly podrobně publikovány již dřive - viz Zůbek 2010 . 


\section{Prameny a literatura}

BORSKÝ, P .-ČERNOUŠKOVÁ, D.-HODEČEK, D., 1996: Nemocnice u sv. Anny, Pekařská ul. Brno, I, II. Rkp. stavebněhistorického průzkumu ulož. v archivu společnosti Archaia Brno, o.p.s.

BRÁZDIL, R.-VALÁŠEK, H.-SOUKALOVÁ, E. a kol., 2010: Povodně v Brně. Historie povodní, jejich př́činy a dopady. Brno.

BUKOVSKÝ, J., 1994: Královopolský kartouz. Brno.

CDM VI: Codex diplomaticus et epistolaris Moraviae VI. (Chytil, J., ed.). Brno 1854.

ČERNÁ, L. a kol., 2013: Černá, L.-Dejmal, M.-Holub, P.-Kolařík, V.-Merta, D.-Peška, M.-Sedláčková, L.-Zbranek, H.-Zůbek, A., Brno (okr. Brno-město), PV 54, č. 2, 148-184.

ČERNÁ, L. a kol., 2014: Černá, L.-Holub, P.-Kolařík, V.-Merta, D.-Peška, M.-Sedláčková, L.-Zůbek, A., Brno (okr. Brno-Město), PV 55, č. 2, 171-205.

ČERNÁ, L.-SEDLÁČKOVÁ, L.-ZŮBEK, A., 2010: Nálezová zpráva o provedení záchranného archeologického výzkumu při stavbě „Fakultní nemocnice u sv. Anny v Brně - stavba ICRC“. Nálezová zpráva č. 2/10 ulož. v archivu společnosti Archaia Brno, o. p. s.

ČERNÁ, L.-ZŮBEK, A., 2013: Nálezová zpráva o provedení záchranného archeologického výzkumu při stavbě „Fakultní nemocnice u sv. Anny v Brně - stavba ICRC - 2. etapa“. Nálezová zpráva č. 23/13 ulož. $\mathrm{v}$ archivu společnosti Archaia Brno, o. p. s.

ČERNOUŠKOVÁ, D.-HODEČEK, D., 1996: Fakultní nemocnice u sv. Anny v Brně. Brno.

ČERNUŠÁK, T., 2013: Řeholní domy. In: Dějiny Brna 2. Stř̌edověké město (Jan, L., red.), 718-742. Brno.

DOLEŽEL, J., 2000: K městskému zrízení na středověkém Brněnsku do roku 1411, Mediaevalia archaeologica 2, 159-259.

DŘÍMAL, J., 1973: Z dějin brněnských předměstí. In: Dějiny města Brna 2 (Dřímal, J.-Peša, V., red.), 255-319. Brno.

FLODROVÁ, M., 1997: Brněnské ulice a vývoj jejich názvů od 13. století po dnešek. Brno.

FLODROVÁ, M.-MÜLLER, Z., 2007: Staré Brno. Vyprávění o minulosti nejstarší části města Brna. Brno.

FOLTÝN, D. a kol., 2005: Encyklopedie moravských a slezských klášterů. Praha.

HOLUB, P.-MERTA, D.-ZŮBEK, A., 2010: Protiletecké kryty v Brně (Dům umění a areál Fakultní nemocnice u sv. Anny), Archeologia technica 21, 129-136.

HOLUB a kol., 2007: Holub, P.-Kolařík, V.-Merta, D.-Peška, M.-Polánka, P.-Sedláčková, L.-Zapletalová, D.-Zůbek, A., Brno (okr. Brno-město), PV 48, 410-461.

HOLUB a kol., 2008: Holub, P.-Kolařík, V.-Merta, D.-Peška, M.-Polánka, P.-Sedláčková, L.-Zapletalová, D.-Zůbek, A., Brno (okr. Brno-město), PV 49, 356-393.

HOLUB a kol., 2009: Holub, P.-Kolařík, V.-Merta, D.-Peška, M.-Polánka, P.-Sedláčková, L.-Zapletalová, D.-Zůbek, A., Brno (okr. Brno-město), PV 50, 345-376.

HOLUB a kol., 2010: Holub, P.-Kolař́k, V.-Merta, D.-Peška, M.-Sedláčková, L.-Zapletalová, D.-Zůbek, A., Brno (okr. Brno-město), PV 51, 395-432.

JAN, L., 2004: Ves a klášter ve středověku (1240-1526). In: Řepa, M. a kol., Dějiny Králova Pole, 26-69. Brno.

KOCMAN, P., 2004: Od nástupu Habsburků na český trůn do zrušení kláštera (1526-1782). In: Řepa, M. a kol., Dějiny Králova Pole, 70-98. Brno.

KOLAŘÍK, V.-MERTA, D.-ZŮBEK, A., 2014: Archeologická topografie levobřeží Svratky v prostoru Starého Brna, Forum Urbes Medii Aevi VIII./1-2, 112-125.

KROUPA, J.-SUCHÁNEK, P., 2015: Staré Brno. In: Dějiny Brna 7. Uměleckohistorické památky. Historické jádro (Kroupa, J., red.), 677-744. Brno.

KUČA, K., 2000: Brno. Vývoj města, předměstí a připojených vesnic. Praha - Brno.

LISÁ, L.-BAJER, A., 2007: Posudek na lokalitu Sv. Anna v Brně. In: Peška, M., FN u sv. Anny v Brně, prŕíprava území ICRC. Nálezová zpráva o provedení zjištovacího archeologického výzkumu. Nálezová zpráva č. 22/07 ulož. v archivu společnosti Archaia Brno, o. p. s.

MEZIHORÁKOVÁ, K., 2016: Architektura středověkých klášterủ dominikánek v Čechách a na Moravě. Praha.

MITÁČEK, J., 2005: Starobrněnští johanité a jižní Morava za vlády Lucemburků (1310-1423), BMD 18, $43-55$.

PEŠKA, M., 2007: FN u sv. Anny v Brně, př́íprava území ICRC. Nálezová zpráva o provedení zjištovacího archeologického výzkumu. Nálezová zpráva č. 22/07 ulož. v archivu společnosti Archaia Brno, o.p. s.

- 2015: Dominikánský konvent sv. Michala v Brně na Rybném trhu. Historie a stavební vývoj do poloviny 17. století v kontextu střední Evropy. Rkp. disertační práce obhájené na Ústavu archeologie a muzeologie Filozofické fakulty Masarykovy univerzity, Brno. 
PROCHÁZKA, R., 1990: Kovové předměty z výbavy středověkého měštana z výzkumu v Brně - Pekařské ulici - Metallgegenstände der Ausstattung der mittelalterlichen Bürgers aus der Ausgrabung in Brno Pekařská ulice, AH 15, 99-109.

- 1999: Brno (okr. Brno-město). Ulice Pekařská č. 53, parcela č. 1752/1, PV 39 (1995-1996), 381-382.

PROCHÁZKA, R.-KOLAŘÍK, V.-ZŮBEK, A., 2013: Předměstí. In: Dějiny Brna 2. Středověké město (Jan, L., red.), 568-600. Brno.

PROCHÁZKA, R.-WIHODA, M.-ZAPLETALOVÁ, D., 2011: V raném středověku. In: Dějiny Brna 1. Od pravěku k ranému středověku (Procházka, R., red.), 447-560. Brno.

ŘEPA, M., 2004: Josefínské a předbřeznové intermezzo (1782-1844). In: Řepa, M. a kol., Dějiny Králova Pole, 99-116. Brno.

SAJNER, J., 1986: Cenná archívní svědectví. In: Sajner, J.-Selinger, L.-Volavý, K., Dvě století ve službách zdraví. Fakultní nemocnice s poliklinikou v Brně na Pekařské. 1786-1986, 9-95. Brno.

SAJNER, J.-SELINGER, L.-VOLAVÝ, K., 1986: Dvě století ve službách zdraví. Fakultní nemocnice s poliklinikou v Brně na Pekařské. 1786-1986. Brno.

SMÍŠEK, K., 2009: Numismatické určení souboru mincí z předstihového archeologického výzkumu společnosti Archaia o. p. s. na lokalitě Brno, Fakultní nemocnice u sv. Anny (A66/2008). Velké Př́lepy. Rkp. ulož. v archivu společnosti Archaia Brno, o. p. s.

VIČAR, O., 1966: Místopis Brna ve 14. století (Předměstí), BMD 8, 226-273.

ZAPLETALOVÁ, D., 2007: Brno, Pekařská 53, Fakultní nemocnice u sv. Anny. ICRC - energoblok. Nálezová zpráva č. 59/07 ulož. v archivu společnosti Archaia Brno, o. p.s.

ZAPLETALOVÁ a kol., 2005: Zapletalová, D.-Čulíková, V.-Jankovská, V.-Lisá, L.-Rybníček, M., Př́ispěvek př́rodních věd a archeologie k historické topografii Starého Brna, Ve službách archeologie 6, 267-274.

ZŘÍDKAVESELÝ, F., 1998: Staré Brno a knížecí hrad, VVM L, 3-12.

- 2013: K otázce knížecího hradu na Starém Brně, VVM LXV, 5-13.

ZŮBEK, A., 2010: Pyrotechnologická zařízení z areálu kláštera dominikánek u sv. Anny v Brně, Archeologia technica $21,123-128$.

- 2017: Nálezová zpráva o provedení záchranného archeologického výzkumu při stavbě „Fakultní nemocnice u sv. Anny v Brně - stavba ICRC - 1. etapa“ (dohled těžby stavební jámy). Nálezová zpráva č. 1/17 ulož. v archivu společnosti Archaia Brno, o. p. s.

ŽÁK, K., 1929: Dějiny kartuziánského kláštera v Králově Poli u Brna. Žd’ár nad Sázavou.

\section{Zusammenfassung}

\section{Die Ergebnisse der im Park des einstigen Altbrünner Klosters Hortus Regis durchgeführ- ten archäologischen Grabungen}

Im vorliegenden Beitrag werden die Ergebnisse der archäologischen Rettungsgrabungen zusammengefasst, die im Zeitraum zwischen den Jahren 2008 bis 2013 im östlich gelegenen Teil des Areals des Brünner Fakultätskrankenhauses bei St. Anna (Pekařská-Str. 53) durchgeführt wurden. Diese umfassten einen relativ ausgedehnten Raum, der ursprünglich Teil der Grundstücke des Hortus regis genannten Dominikanerinnenklosters mit der St. Annen-Kapelle war. Das Kloster wurde im Jahr 1312 gegründet und im Jahr 1782 aufgelöst. Anschließend entstand dort eine k. u. k. Allgemeine Versorgungsanstalt, die im Jahr 1856 in ein öffentliches allgemeines Landeskrankenhaus umgewandelt wurde.

Der von den hier behandelten archäologischen Grabungen betroffene Raum ist mit seiner topographischen Lage ein wichtiger Ort in der mittelalterlichen Geschichte des Brünner Gebietes. Im älteren Zeitabschnitt (11.-12. Jahrhundert) befand er sich in der Nähe des ehemaligen Machtzentrums in Alt Brünn, ab der Entstehung der Stadt im 13. Jahrhundert war er hingegen Bestandteil der nächsten Vorstadtstruktur. Der Ort selbst hatte keine günstigen Bedingungen für eine Besiedelung. Es handelte sich um das natürliche Überschwemmungsgebiet des Schwarza-Mühlgrabens (ursprünglich wohl ein Nebenarm des Flusses Schwarza/Svratka). Wahrscheinlich war es vernässt, woran auch das von den Hängen des Spielbergs abfließende Wasser seinen Anteil haben konnte, entlang dessen Fuß es sich sich erstreckte. 
Dass der Raum siedlungsmäßig unattraktiv war, wurde von den Ergebnissen der archäologischen Grabungen bestätigt. Weder für die Urzeit noch für das Mittelalter wurden keinerlei Spuren von menschlichen Siedlungen verzeichnet. Diese wurden in weniger von Überschwemmungen bedrohte Lagen gelegt. An einem solchen Ort wurde auch das Dominikanerinnenkloster und dessen Vorgänger, der königliche Herrenhof, errichtet. Deren Relikte und eventuelle Anzeichen für eine ältere Besiedelung müssen im Bereich des Krankenhaushauptgebäudes in unmittelbarer westlicher Nachbarschaft der untersuchten Fläche gesucht werden.

Der untersuchte Raum war offenbar landwirtschaftlich genutzt worden. Bei einer Überschwemmung des Gebietes und der wohl häufigen Vernässung des Geländes musste er nicht für die Feldwirtschaft hergerichtet werden, sondern konnte dafür genutzt werden, Nutzbäume zu setzen. Diese Tatsache könnte sich auch in der Aussage der ersten schriftlichen Quellen widergespiegelt haben. Im Klosterbestand von 1312 wird neben dem königlichen Hof ein Obstgarten und ein Garten erwähnt, von einem Hof mit Obstgarten ist auch in einem Nachlass aus dem Jahr 1333 die Rede. Während der Existenz des Klosters ist dort dessen Garten angesiedelt, was für die jüngere Zeit durch ikonographische Quellen belegt wird. Es besteht jedoch die Frage, ob diese Grundstücke dem Kloster bereits seit dessen Anfängen gehört hatten. Nach der Auflösung des Klosters wurden sie zum Garten des Versorgungsanstalt und anschließend zum Park des Krankenhauses.

Durch die archäologische Grabung wurde eindeutig nachgewiesen, dass das Gebiet das ganze Mittelalter über und offenbar auch im darauffolgenden Zeitraum überschwemmt gewesen war. Für das 18.-19. Jahrhundert war die Aussage der archäologischen Quellen nicht so eindeutig, jedoch ist es wahrscheinlich immer noch zu Überschwemmungen gekommen. Der Schwarza-Mühlgraben stellte eine unmittelbare Bedrohung dar. Jedoch muss auch mit dem Fluss Schwarza selbst gerechnet werden.

Die archäologischen Situationen waren nicht unausgeprägt, und in gewisser Hinsicht mangelte es ihnen ganz zweifellos nicht an Interessantheit. Dokumentiert wurde eine Reihe von Erdaushubaktivitäten unterschiedlichen Charakters. Die erste stammt aus dem 14. Jahrhundert, also aus der Zeit der Entstehung und Errichtung des Klosters. In der Neuzeit intensiviert sich ihr Auftreten und dauert auch in der Zeit an, als sich der Klostergarten zum Park des Krankenhauses wandelte. Ihr jeweiliger genauer Zweck konnte meist nicht aufgedeckt werden. Dass es sich nicht nur um „unbedeutende“ Gruben handelte wird in einigen Fällen durch ihren Charakter angedeutet (z.B. Ausdehnung, regelmäßiger Grundriss, Spuren senkrechter Konstruktionselemente aus Holz, spezifische Verfüllung - siehe etwa die Schotterfüllungen mittelalterlicher Gräben oder die mit feinem gelben Sand gefüllten neuzeitlichen Gruben).

Eines der markantesten neuzeitlichen Objekte war ein Wasserreservoir. Es hat als Zuchtteich dienen können, um die Klostergemeinschaft mit Fisch zu versorgen. Sein Vorhandensein konnte bis zu einem gewissen Grad auch dazu beitragen, den Wasserhaushalt in dem betreffenden Raum zu stabilisieren. Im Garten waren auch gewisse Produktionsprozesse untergebracht. Das wird durch vier eingetiefte Öfen eindeutig belegt. Diese hatten jeweils einen unterschiedlichen Charakter. Man kann sie mit der Lebensmittelherstellung in Verbindung bringen. Die beiden ältesten gehörten zur abschließenden Etappe der Existenz des Klosters, der jüngste Ofen diente in der zweiten Hälfte des 19. Jahrhunderts bereits dem Krankenhausbetrieb. Die Grabung lieferte keine klaren Belege für das Vorhandensein irgendwelcher Gebäude. Jedoch lässt sich ihre Existenz nicht völlig ausschließen (vor allem was „leichtere“ Konstruktionen anbelangt). Eine interessante Erscheinung war, dass große Teile des Gartens in seinen östlichen Partien von einer Schotterschicht bedeckt waren. Eine Eindeckung damit erfolgte wiederholt, zweimal im 14.-15. Jahrhundert und einmal in der zweiten Hälfte des 17. und im 18. Jahrhundert. Ziel war dabei offensichtlich, das Gehniveau des vernässten Geländes zu befestigen. Es ist nicht ausgeschlossen, ob dies nicht im Zusammenhang damit erfolgte, den Ort für weitere Tätigkeiten zu nutzen.

Von den Aktivitäten des 20. Jahrhunderts wurde lediglich der Dokumentation verschwundener Luftschutzbunker aus der Zeit des Zweiten Weltkriegs erhöhte Aufmerksamkeit 
entgegengebracht. Freigelegt wurden die Relikte von vier Objekten. Dabei handelte es sich um aus Beton gebaute gangförmige Gebilde. Die Decke bestand aus einem flachen Tonnengewölbe.

Mgr. Antonín Zůbek, Ph.D., Archaia Brno, o.p. s., Bezručova 15, 60200 Brno, Česká republika, azubek@archaiabrno.cz 
